\title{
Chapter 6 \\ Ecuadorian Migration in Amsterdam and Madrid: The Structural Contexts
}

The scope of this chapter is to outline the main characteristics of the two contexts that were the scenario of the phenomenon that is the object of this book. The analysis will centre on those structural features of the cities of Amsterdam and Madrid and, more in general, of the Netherlands and Spain, that may have had an influence on the experience of Ecuadorian irregular migrants.

The chapter will be divided into two parts. In the first, the main features of the Ecuadorian emigration phenomenon will be described. In the second part, a comparative analysis of the structural characteristics of the two receiving contexts will be presented. Following the systemic approach introduced in the first part of this study, the attempt will be to sketch, although in very general terms, some of the features exhibited by the different social systems in Amsterdam and Madrid. To accomplish this goal, a more general discussion about the Netherlands and Spain will be presented and this will focus on five areas that are especially significant to the irregular migration phenomenon: A. migration history and contemporary trends; B. the migration regime ${ }^{1}$; C. the economy and labour market; D. the welfare state; E. the political and public opinion in relation to migration.

Since the Ecuadorian emigration phenomenon has followed a characteristic temporal pattern, with massive outflows condensing between 1999 and 2006, our analysis of the two destination contexts will focus on the period 1998-2013. The migrants interviewed during the fieldwork, realized in 2013, were all part of the mentioned flux, with few limited exceptions.

Although for both Amsterdam and Madrid, and more in general for the Netherlands and Spain, a vast and extremely valuable literature is available on migration and specifically on irregular migration, in this chapter there will be not a systematic discussion of it. This choice does not mean underestimating the importance of the previous works and their results but, rather, it is intended as part of a strategy aimed at limiting, as much as possible, the introduction of "external", pre-constructed inter-

${ }^{1}$ For the concept of migration regime see (Cvajner, Echeverría, \& Sciortino, 2018). 
pretative frameworks at this stage. The aim is to allow a more spontaneous and "inmediate" analysis of the relation between the structural contexts and the results of the empirical research presented in Chap. 7. For this reason, while references to the existing literature will be offered, the discussion will focus mainly on data and figures offered by datasets, official reports and empirical research. Regarding the use of statistical data, given the ample variety of sources available, what was chosen was to privilege the international sources (OECD, Eurostat, World Bank) over the national ones (Centraal Bureau voor de Statistiek and Instituto Nacional de Estadística), when not possible otherwise. Although this option has some disadvantages, related to the fact that national statistics are usually more precise and disaggregated, the advantages lie in the easier and more direct comparability of the international data, a crucial aspect for a comparative research endeavour. This notwithstanding, it is important to be keep in mind the mentioned weaknesses and assume a dose of caution when proposing conclusions built upon this type of data.

\subsection{Ecuadorian Emigration}

Although Ecuadorian emigration has been going on in small numbers since the 1970s, the phenomenon reached massive proportions at the end of the past-century. After 1999, and within a matter of a few years, almost an eighth of the entire population (Herrera, 2008; Herrera, Moncayo, \& Escobar, 2012; INEC, 2013) left the country in search of a better future abroad. This dramatic change in the migratory pattern of the country was mostly determined by the serious economic and financial crisis that hit the country and culminated with the freeze of private bank accounts in 1999 and the dollarization of the economy in 2000. These outcomes were the result of a long-term process of social and political conflict characterized by corruption, economic inefficiency and the slow but continuous erosion of the political system (Acosta, 1998; Echeverría, 1997; Ramírez \& Ramírez, 2005).

Probably the most noticeable effect of the systemic crisis was precisely the sudden and massive migratory outflow. Until 1998, emigration had been relatively limited and registered numbers that were inferior to a thousand per year. Things changed in 1999 when the flux reached hundreds of thousands (Boccagni, 2007). From this moment on, and for the next decade, the outflows presented unprecedented figures (see Fig. 6.1). In the years 2000 and 2002 fluxes peaked above 150,000 people per year. The remittances sent by migrants soon became the second source of national income, passing from 794 million USD in 1998 to 2318 in 2005 (Herrera, 2007; Herrera et al., 2012). The magnitude of the phenomenon changed the social and political understanding of migration; those that once had been considered betrayers started to be considered heroes. The expatriate community was designated officially as the Fifth Region of the country (in addition to the traditional four) and its participation in domestic political life was strongly encouraged (G. Echeverría, 2014a).

The three most important destinations of Ecuadorian migration were Spain, the United States and Italy (Herrera, 2008). However, Spain received by far the largest 


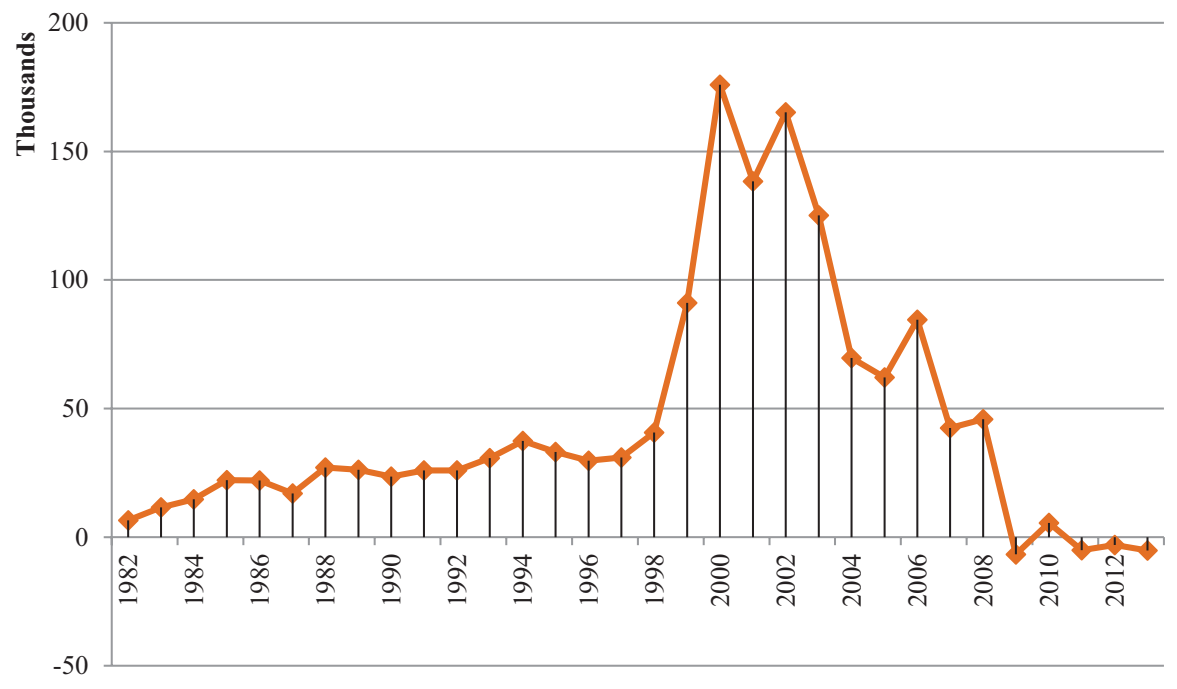

Fig. 6.1 Ecuadorian emigration (Data from: FLACSO-UNFPA, 2008 and INEC, 2013)

part of the flux. This has been related to a number of factors, such as: the common language, the cultural affinity, the visa-free entry and the booming economy at destination (Gómez Ciriano, Tornos Cubillo, \& Colectivo IOE, 2007; Herrera et al., 2012). In 2005, Ecuadorian-born immigrants living in Spain reached a peak of 487,239 but slightly decreased in the following years (Eurostat). The other European countries received smaller numbers of Ecuadorian migrants. The Netherlands reached a peak of 3028 Ecuadorian-born people in 2014 (Eurostat).

It was only in 2007 and 2008, as a result of both the improved economic conditions in Ecuador and the beginning of the economic crisis in the US and Europe, that the fluxes went back to the pre-crisis standards. In 2009, and in the following years, since a return-migration phenomenon emerged, net migration registered negative values for the first time in recent Ecuadorian history. The magnitude of these flows, however, never reached the level of those of the previous phase. Although a growing number of those who had left considered the option to return, a large majority decided to remain abroad (Herrera et al., 2012).

\subsection{The Netherlands as Irregular Migration Context}

\subsubsection{Migration History and Contemporary Trends}

After the end of WWII and for the next decade, the Netherlands was a country of emigration. This pattern radically changed in the early 1960s. From that moment on, and regardless of the self-perception of its political leaders, which continued to officially refuse that reality until the 1990s, the country has constantly been an important migration destiny. 


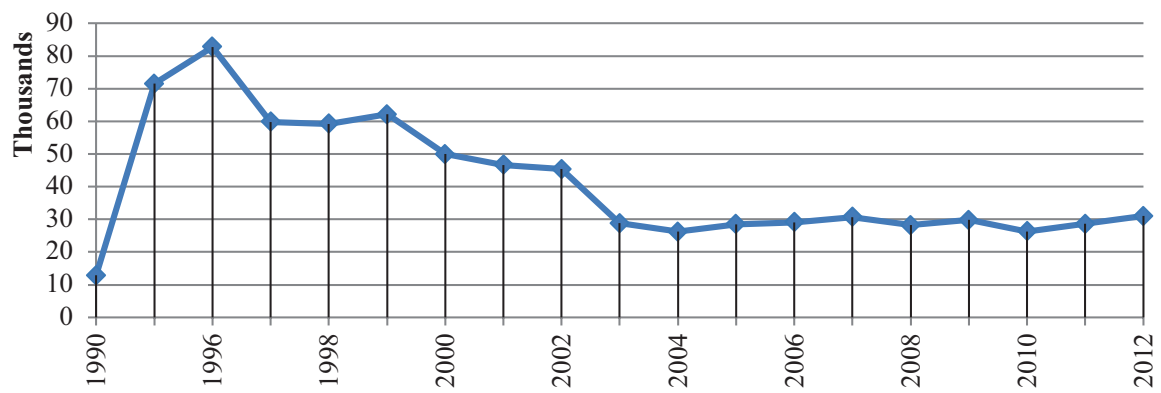

Fig. 6.2 Asylum seeker requests (Eurostat)

Migration researchers have identified a number of important, successive migratory waves in the recent history of the Netherlands (Broeders, 2009; Leerkes, 2009; Lucassen, 2001; Van Meeteren, Van de Pol, Dekker, Engbersen, \& Snel, 2013). The first one took place between the early 1960s and the oil crisis of 1973. This wave involved labour migrants arriving in the Netherlands as guest workers from Mediterranean countries, such as Spain, Italy, Portugal, Turkey and Morocco. In the intentions of the Dutch government, these migrants were expected to stay only temporarily and leave the country once their labour contracts had ended. Yet, this plan turned out to be wrong; the vast majority of migrants, and especially those from Turkey and Morocco, decided to stay, establishing significant communities in the main cities.

The second migratory wave was very much related to the first one. Contrary to political prediction, not only did former guest workers not leave after the recruitment ban but, thanks to the existing legal framework, they were able to bring their families to the Netherlands. Moreover, as second generations started to develop, many young males brought spouses from their origin countries. Since the mid-1970s and until our days, these channels have allowed a continuous flux of new emigrants, especially from Turkey and Morocco.

A third important migratory wave involved migrants arriving from former Dutch colonies. These fluxes started in 1975 after the independence of Suriname. In the following years, almost one third of the entire population left the South American country. Furthermore, in the late 1980s, a new stream of immigrants started to arrive in the Netherlands from the Dutch Antilles.

A fourth wave of immigration emerged in the late 1980s and involved asylum seekers (see Fig. 6.2). This flux became particularly relevant in the 1990s when a number of wars and humanitarian crises in Europe and in neighbouring areas determined a sharp increase in asylum requests. Given the generosity of the existing legal framework, the Dutch government had its hands tied once a request was issued and the rate of acceptance was very high. This phenomenon contributed to the so-called "migration crisis" of the 1990s and a political backlash that fostered a serious revision of the migratory and asylum regime in the years to follow.

Finally, a fifth wave of immigration emerged in the 2000s. This flux involved mainly labour migrants from Western countries and in particular from Eastern European countries such as Poland, Bulgaria and Romania. 


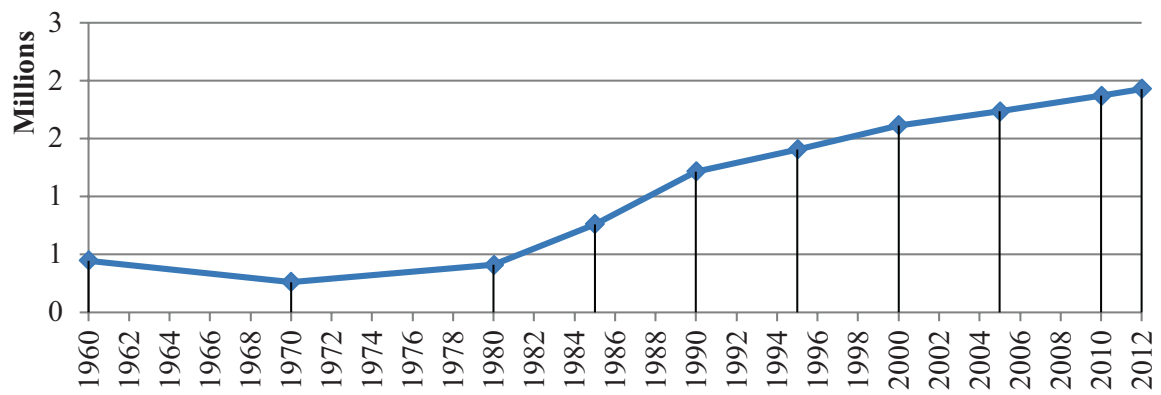

Fig. 6.3 Foreign-born population. (Data from: OECD)

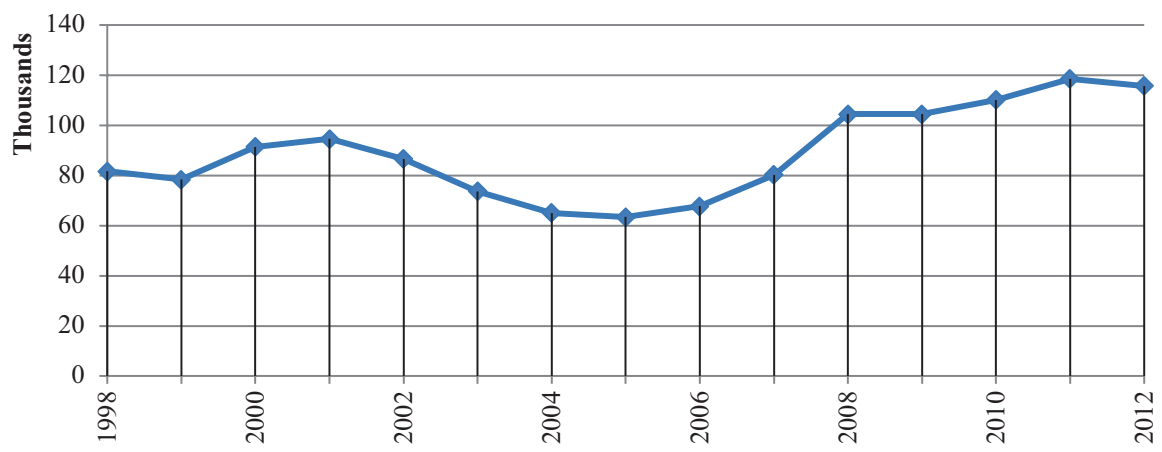

Fig. 6.4 Annual migration inflow. (Data from: OECD)

In 2012, of a total population of 16,730,348 individuals, the foreign-born population in the Netherlands counted 1,927,700 individuals, which represented $11.5 \%$ (OECD). The population with a foreign background counted 3,494,193 individuals and represented $20.9 \%$ (CBS). This outcome was the result of more than 50 years of continued migration inflows (see Fig. 6.3).

As regards the yearly inflow of new migrants during the 1999-2012 lapse (see Fig. 6.4), a mixed picture emerges. Between 1998 and 2001, the fluxes slightly grew to reach almost 100,000 new arrivals in 2001; from 2001 to 2005 , a significant decrease was observable, with a minimum of 60,000 new entries in 2005; from 2005 on, fluxes started to grow again and reached a maximum of almost 120,000 in 2011.

\subsubsection{Irregular Migration Estimations}

A number of estimations of irregular migrants residing in the Netherlands have been produced in the last decade (Engbersen et al., 2002; Hoogteijling, 2002; Leerkes, van San, Engbersen, Cruijff, \& van der Heijden, 2004; van der Heijden, Cruyff, \& 


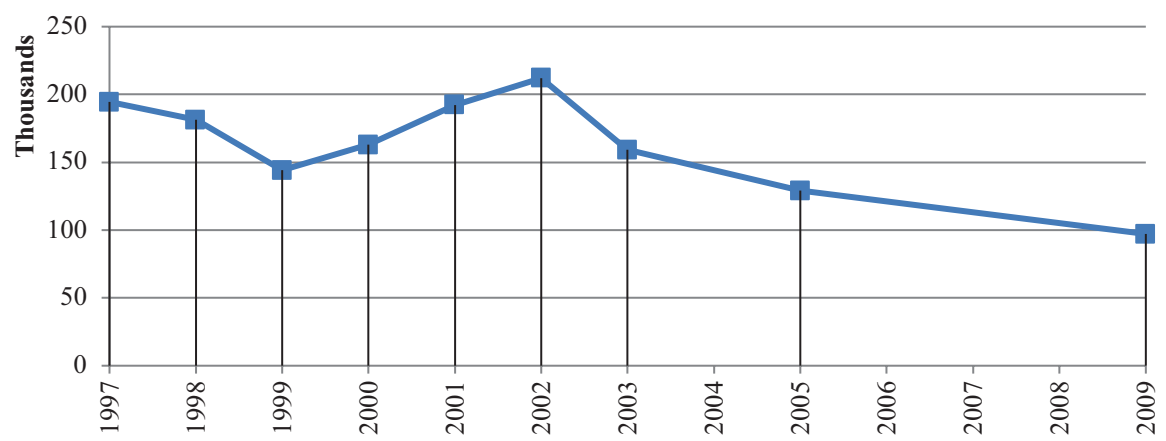

Fig. 6.5 Irregular migration estimation. (Data from: INDIAC - NL EMN NCP (2012)

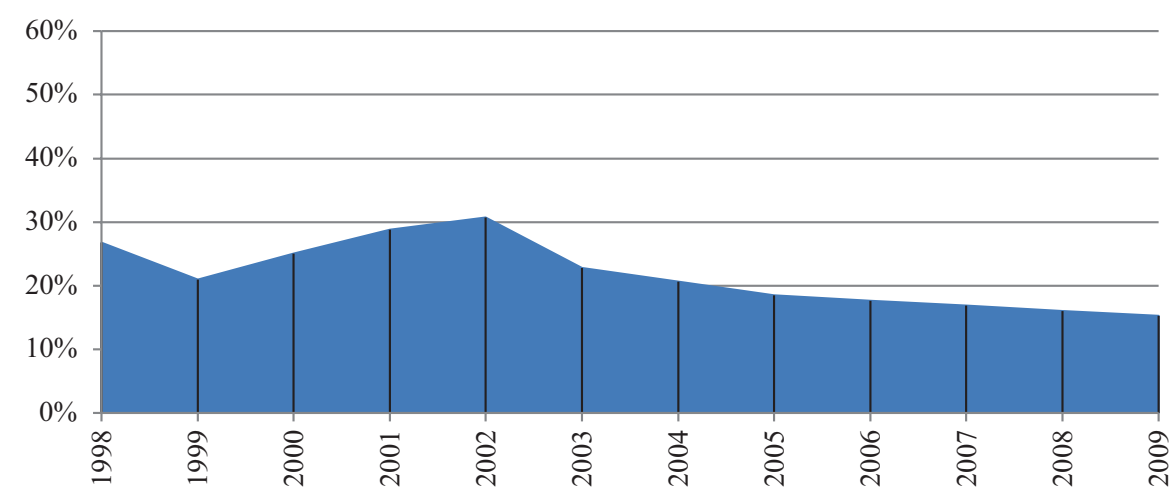

Fig. 6.6 Irregular-migrant percentage of total foreign population (Own elaboration, data from: INDIAC - NL EMN NCP (2012) and Eurostat

van Gils, 2011; van der Heijden, Gils, Cruijff, \& Hessen, 2006). Van der Leun and Illes have comprehensively discussed the different methodologies and approximations used by researchers, as well as the main pros and cons of their works. As they pointed out: "methods have been fine-tuned and the quality of available data has gradually improved as a result of increased co-ordination between different government branches and on-going computerization" (Van Der Leun \& Ilies, 2008, p. 13).

As can be observed (see Figs. 6.5 and 6.6), the first data available estimated a population of approximately 200,000 irregular migrants in 1997 . This figure represented more than $25 \%$ of the total foreign population. In the next 2 years, numbers slightly fell to start growing again in the year 2000 . The rising trend lasted for the next 2 years. In 2002, the irregular-migrant population in the Netherlands reached a historic maximum of 211,990 individuals (INDIAC - NL EMN NCP \& Diepenhorst, 2012, p. 83), which represented more that $30 \%$ of the foreign population. Since that year, an opposite and prolonged decreasing trend has been registered. 
As underlined by the 2012 Report, Practical measures for reducing irregular migration in the Netherlands, an important part of the explanation for this reduction is related to the European Union's enlargements in 2004 and 2007, which determined the automatic regularization of Bulgarian and Rumanian citizens (INDIAC NL EMN NCP \& Diepenhorst, 2012, p. 84). The last available data show for the year 2009 an irregular-migrant population of nearly 100,000 individuals, which represented $15 \%$ of the total foreign population.

As summarized by Leerkes, a number of general features characterize the irregular population in the Netherlands. The phenomenon is concentrated in certain agricultural areas and in deprived urban neighbourhoods where irregularity can reach $6 \%$ or $8 \%$; irregular migrants originate from more than 200 countries and the largest groups are Turks, Moroccans, Algerians and Surinamese; refused asylum seekers are estimated to constitute $15 \%$ of the irregular population (Leerkes, 2009, p. 16).

\subsubsection{Migration Regime}

Migration scholars have distinguished three phases in the ways in which the Dutch society has dealt with the arrival and residence of irregular migrants (Broeders, 2009; Engbersen, 2001).

The first, corresponding to the decade of the 1960s, was characterized by the "welcoming of 'spontaneous migrants' who could easily be legalized and employed in factory work and agriculture" (Engbersen, 2001, p. 241). The second phase, from 1970 to 1991 , was that of "the silent toleration of 'illegal workers', which enabled them to gain access to the formal labour market and take care of themselves" (Engbersen, 2001, p. 241). Irregular migrants during those years "were duly regularized as they found a job" (Kloosterman, Van Der Leun, \& Rath, 1999). Broeders has described this phase as characterized by the application of the traditional Dutch principle of gedogen (Broeders, 2009, p. 63). This principle, of which he proposes a translation into English using the term toleration, implied an intentionally weak application of the formal legal framework.

Irregular migrants, once established, are able to find work even in the formal labour market. They can still obtain Social-Fiscal numbers (so-called SoFi numbers), which allow them to hold tax-paying jobs. The enforcement regime on irregular labour is lax and in a number of sectors such as agriculture and horticulture, where despite the high unemployment figures employers find it difficult to fill the vacancies, the authorities often turned a blind eye (Broeders, 2009, p. 63)

The third phase, which started in 1991 and is currently on-going, has been characterized by a radical change in the political and legal approach towards irregular migration. Engbersen has summarized the new paradigm as directed at "excluding and deporting "illegal aliens"” (Engbersen, 2001, p. 241). A number of consecutive legal reforms and new administrative regulations have been approved with the objective of reducing the irregular migration population. Several research works have analysed the scope, evolution and consequences of these interventions 
(Broeders, 2009; Broeders \& Engbersen, 2007; Engbersen \& Broeders, 2009; Engbersen \& Van Der Leun, 2001; Engbersen et al., 2004; Kloosterman et al., 1999; Leerkes, 2009, 2016; Van Der Leun, 2003, 2006; Van der Leun \& Bouter, 2015; Van Der Leun \& Ilies, 2008; Van Meeteren, 2010; Van Meeteren et al., 2013).

The strategy adopted by the Dutch government has been threefold (see for instance: Broeders, 2009; Leerkes, 2009). A first group of measures had the objective of limiting the entry of new irregular migrants. Crucial actions in this area, often adopted in coordination with the European Union partners, have been: A. the enforcement of stronger and more sophisticated border control systems; B. the tightening of visa policy both for tourist and workers (tougher conditions, extension of the list of countries with visa obligation); C. the limitation of family reunification and stricter marriage policies; D. the fight against human trafficking; E. the sharpening of asylum policy; F. the adoption of limited regularization processes directed towards long-term asylum seekers.

A second group of interventions has focused on making residence for irregular migrants more difficult and costly. The two pillars of this policy were: the exclusion of irregular migrants from important institutions of the welfare state and the fight against irregular employment. As regards the first objective, the most important step was taken with the adoption of the Linking Act (Koppelingswet) in 1998. This provision established a link between the possibility to access public services, such as, social security, health care, education or public housing, and the holding of a valid residence permit. Concerning the second objective, numerous actions have been adopted since the early 1990s, for instance: A. the denial of social security and tax numbers to irregular migrants; B. the obligation for employers to check employees' documentation; C. the increase of fines for dishonest employers; D. the allocation of more resources and personnel to the labour inspection service. The implementation of all these policies required fundamental and recurrent improvements to the database and information exchange systems at all the administration levels.

A third group of policies was aimed at making the apprehension, identification and expulsion of irregular migrants more efficient. The actions taken to achieve this goal included: A. tighter policy on individuals' identification obligation; B. stricter controls of employment places; C. the implementation of sophisticated identification technologies; D. improvement of the detention policy (new facilities and longer detention times); E. readmission agreements with third countries; F. improvement of database and information exchange systems at a European level.

\subsubsection{Economics, Labour Market and Underground Economy}

As can be observed in Fig. 6.7, the Dutch Gross Domestic Product (GDP), used here as a general indicator of the economic trends, shows a fluctuating picture within the considered lapse of years. Between 1998 and 2001, the economy markedly grew, with a peak in the year 1999 with an over 4\% variation. Years 2002 and 2003 were characterized by stagnation. In the next 5 years, until 2008, the economy grew 


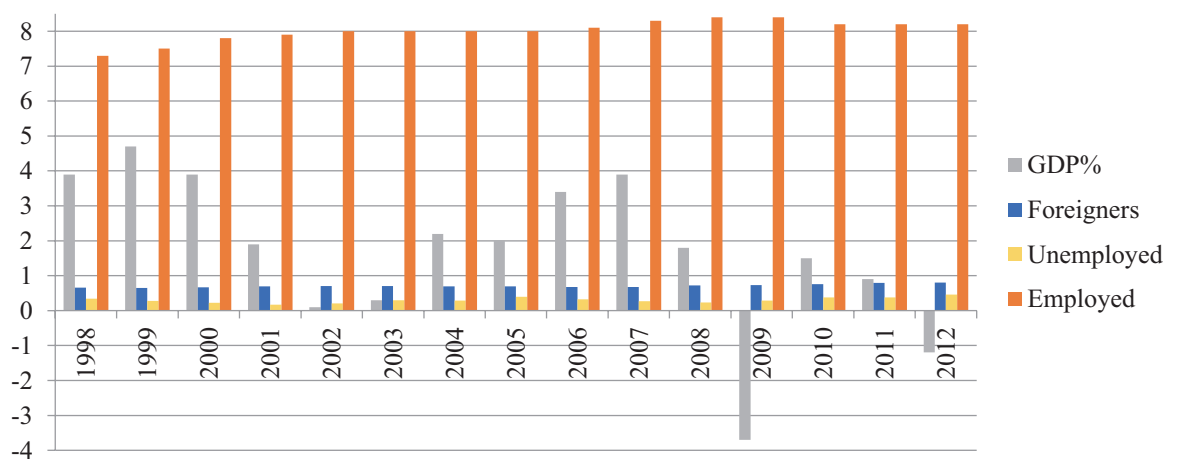

Fig. 6.7 GDP variation, employment, unemployment, migration. (Data from: Eurostat. Foreigners, Employed and Unemployed are in millions per year)

again, especially in 2006 and 2007 when the variation was over 3\%. The effects of the economic crisis hit the Dutch economy severely in the year 2009, when the GDP registered a $-3.7 \%$ fall. A slight recovery was observable in 2010 and 2011, when the GDP averaged a $1 \%$ annual growth. Nevertheless, the economy contracted again in 2012 , registering a $-1.2 \%$ variation.

Concerning the labour market and in particular total employment, a growing trend has been observable. In the year 1998, the number of employed people was $7,347,100$. After 14 years, in 2012, the number rose to $8,254,100$. The number of jobs created in this lapse of time was 907,000 . It is possible to witness a direct, however slightly delayed, correlation between the GDP and the jobs created. The years when the economy grew were those when also the labour market expanded. On the contrary, a contraction of the GDP, like the one that occurred in 2009, determined a significant destruction of jobs. A year later, in 2010, the labour market had lost 216,500 jobs.

As regards the unemployment, an inverse, slightly delayed, correlation with the GDP has been observable. In general (see Fig. 6.8), very low numbers have been registered. The peak was reached in 2012, when 460,000 people were unemployed; they represented $5.57 \%$ of the active population.

With regard to the occupation structure (see Fig. 6.9), the Dutch labour market did not undergo noteworthy changes in the considered years. In 1998, highly skilled occupations (International Standard Classification of Occupations - ISCO are used), such as Managers, Professionals, and Technicians and Associate Professionals, represented 46\%; 14 years later, the same group had fallen one percentage point to 45\%. In the same years, Elementary Occupations, passed from 7\% to $8.3 \%$ in 2012.

Finally, as regards the underground economy (see Fig. 6.10), the estimations produced by Schneider and his colleagues for the Netherlands, evidence a decreasing trend in the considered years (Schneider et al., 2010; Schneider, Raczkowski, Mróz, \& Futter, 2015). In 1999, the underground economy represented 13.3\%; in 2014 it had fallen to $9.2 \%$. Both percentages are way below the European Union (28 countries) average, which scored a 20.3\% in 1999 and $18.6 \%$ in 2014. 


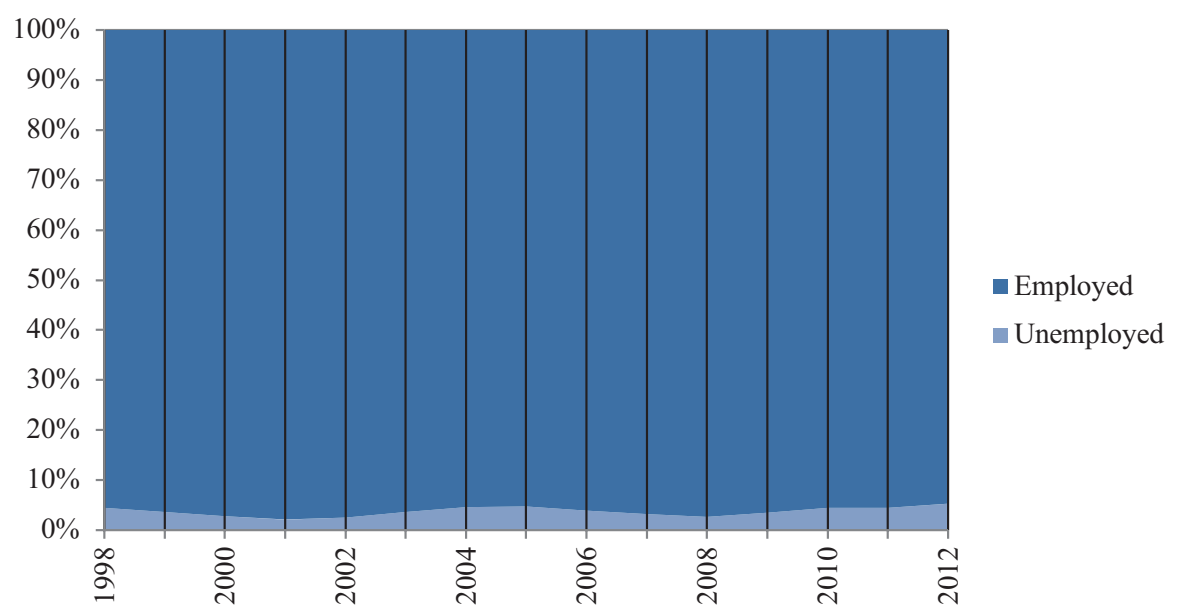

Fig. 6.8 Labour market structure. (Data from: Eurostat. Foreigners, Employed and Unemployed are in millions per year)

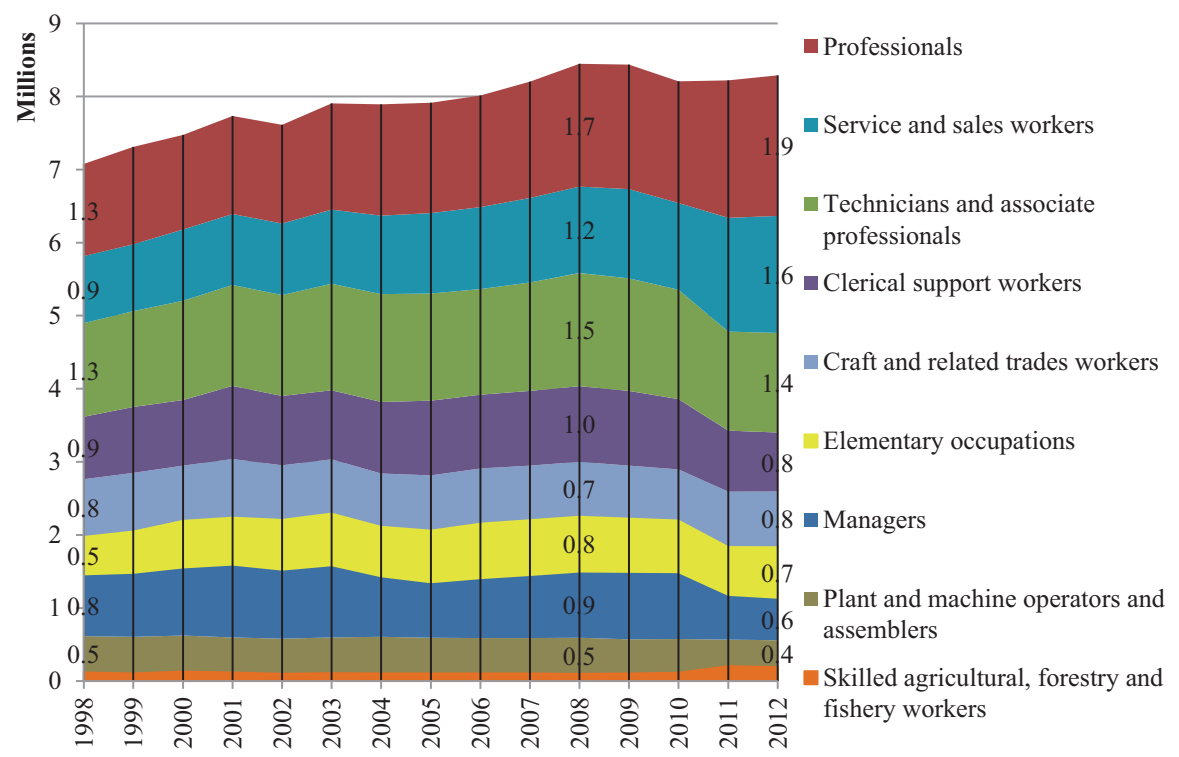

Fig. 6.9 Main occupations. (Data from: Eurostat)

\subsubsection{The Welfare Regime in the Netherlands}

Within the different welfare state clusters in Europe, the Dutch welfare state is usually placed under the heading of the so-called Continental Welfare Regimes (EspingAndersen, 1990, 1996b; Ferrera et al., 2000; Hemerijck, 2012; Hemerijck, Keune, \& Rhodes, 2006; Hemerijck, Palm, Entenmann, \& Van Hooren, 2013). Hence, its 


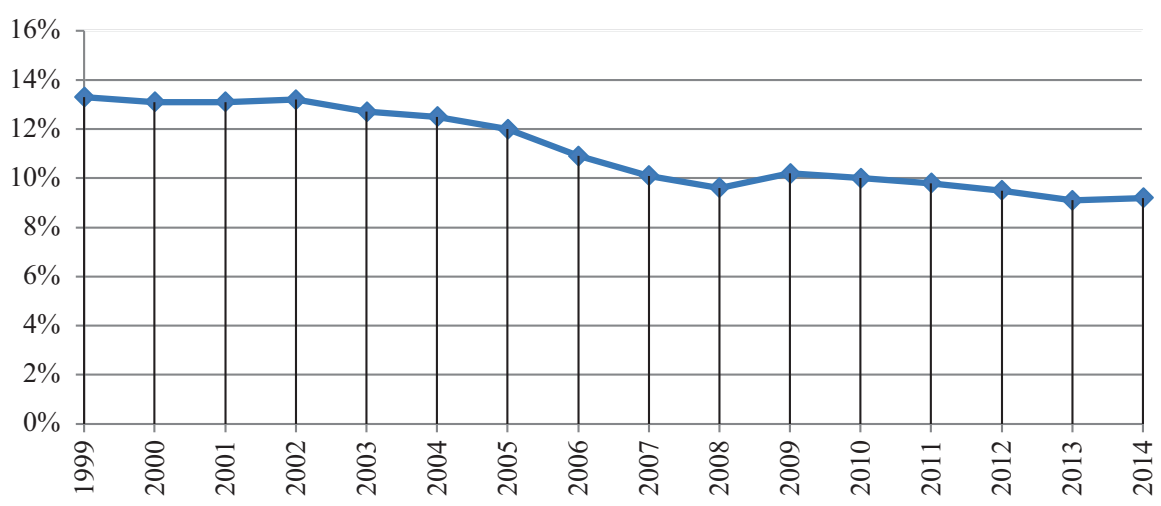

Fig. 6.10 Underground Economy. (Data from: Schneider et al., 2010, 2015)

original conception was based on the Bismarckian tradition. Following the social insurance model, "a tight link between work position and/or family status and social entitlements" (Hemerijck et al., 2013, p. 21) was established. As pointed out by Hemerijck and his colleagues, the influence of the Christian tradition and, in particular, of Calvinism was strong behind this conception. "The Calvinist emphasis on individual responsibility makes Calvinism rather suspicious of establishing poor relief programs without enforcing work discipline, next to only meagre relief"' (Hemerijck et al., 2013, p. 21).

The insurance model was functional to "the status maintenance and the support of traditional male breadwinner nuclear family structures" (Hemerijck et al., 2013, p. 21). Accordingly, the labour market was strongly regulated and focused on enabling the possibility of long, stable, remunerative careers. Women were discouraged from participating in the labour market, they received "indirect social protection though derived male breadwinner stable employment, social insurance and passive familiar benefits" (Hemerijck et al., 2013, p. 21). Within this model, those who were unable to follow the job-insurance path had to rely on a network of local social assistance organizations.

While the Bismarckian tradition was at the base of the Dutch welfare state, a number of features indicated a certain distance from orthodoxy. In particular, the provision of basic public pension, the tax-financed minimum social assistance and the public financing of elderly care services clearly signalled a departure from a strict insurance model (Hemerijck et al., 2013, pp. 21-22).

The Dutch welfare state has undergone a process of radical reforms since the 1980s and increasingly in the 1990s and 2000s. These reforms implied "an explicit U-turn away from the Continental pathology of "welfare without work" towards embracing a more inclusive and activating welfare state" (Hemerijck et al., 2013, p. 27). Similarly to what occurred in the rest of Europe, welfare state recalibration was largely motivated by the deep and complex structural changes affecting societies and states (Esping-Andersen, 1996a; Ferrera, 2008; Ferrera et al., 2000; 
Hemerijck, 2012). Within the new demographic, productive and competitive conditions, the very sustainability of the welfare state was at stake.

The changes introduced by the successive reforms in the Netherlands implied the gradual move away from Bismarckian employment-related social insurance towards a basic universal income support based on general taxation. "Fighting poverty has become a new distributive priority, that implied a shift in attention from insiders (male breadwinners, their dependents and societal representatives) to outsiders (women, low-skill groups and others)" (Hemerijck et al., 2013, p. 28). This shift was complemented by a comprehensive reform of the labour market policy. The emphasis in this area was now placed on the activation and increasing insertion of previously- excluded sectors of the population (women, the elderly the unemployed, low-skilled workers and migrants) in the labour market. The new paradigm was captured by the concept of "flexicurity". The agreement between the government, the trade unions and the employers, in 1995, allowed a flexibilization and diversification of the types of contracts in exchange for a universal protection system. Successive reforms $(2000,2002)$ further extended the labour rights and protections connected to flexible contracts, leading to a de facto equalization with those granted by permanent contracts. In the field of activation, a number of measures were taken through the late 1990s and 2000s, and the objective was to incentivize work at all levels. The measures included: A. the implementation of counselling and permanent training systems for the unemployed; B. the discouragement of early pensions and the reduction of disability benefits; $\mathrm{C}$. the implementation of policies to reconcile work and family life through parental leave incentives, subsidies, tax deductions.

These important transformations of the Dutch welfare state required "strengthening the role of the central government and local authorities, at the expense of the social partners" (Hemerijck et al., 2013, p. 28). Moreover, both the promotion of active labour market policies and the development of more sophisticated systems to provide social services required a continuous modernization of the administrative apparatus. All in all, as pointed out by Broeders, the Netherlands has an "elaborate welfare state with a high level of social protection, which requires a keen eye for matters of eligibility. Most sectors of public and semi-public life are highly regulated and subject to registration and documentary requirements by a professional and well-staffed bureaucracy" (Broeders, 2009, p. 40).

\subsubsection{Politics, Public Opinion, Migration}

After three decades of sustained migrations and the development of important communities of emigrants in the main cities, in the early 1990s the Dutch government still refused to officially recognize the Netherlands as a country of immigration (Van Meeteren et al., 2013). A historic step was taken in 1998, when the role of migration was officially acknowledged as central to the Dutch society. Yet, this step, which caused heated debates in the Parliament, was nothing more than an act of self-conscience or self-recognition. 
While the reality of immigration had been officially understated, the Dutch government had been actively dealing with it since the 1970s. In those years migration had been generally welcomed. As pointed out by Kloosterman and his colleagues: "only three decades ago, the Dutch government welcomed undocumented immigrants who were represented as 'spontaneous guestworker'. They were duly regularized as soon as they found a job" (Kloosterman et al., 1999, p. 252). As regards the integration of the newcomers, a multiculturalist approach was adopted (Entzinger, 2006; Van Meeteren et al., 2013). Migrants should integrate while preserving their ethnic identity: "the emphasis was on self-organization and arrangements for education in minorities' own languages. [...] The immigrant integration policy aimed at mutual adaptation and equal opportunities for Dutch people and ethnic minorities" (Van Meeteren et al., 2013, p. 118).

The multiculturalist perspective became criticized in the 1990s. Migrant communities showed significantly higher levels of unemployment, welfare dependency and marginalization. The new approach, then, focused on the socio-economic integration of migrants. "Integration was interpreted as equal participation in the major social institutions of society" (Van Meeteren et al., 2013, p. 119).

In the early 2000s, the government's approach towards migrations underwent another transformation. While the political and social attitude towards migration had been deteriorating since the 1990s, in connection to the increasingly conflictual relations with the immigrant communities and the sustained arrival of new flows, the first years of the new millennium meant a turning point. On the one hand, a number of dramatic episodes at a national and international level, for instance, the assassination of Pim Fortuyn (2002) and Theo Van Gogh (2004) or the 9/11 terrorist attacks, raised the alarm about the effective integration and possible "integrability" of the immigrant communities and especially of those of Muslim religion. On the other, populist Dutch Politicians, such as Pim Fortuyn, Ayaan Hirsi Ali or Geert Wilders, cleverly exploited these events to support their claims. Slogans like: "the Netherlands is full" and "multiculturalism has failed" became part of a heated public debate (Garcés-Mascareñas, 2011; Penninx, 2006; Van Meeteren et al., 2013).

The changed climate transformed into political action. The new emphasis of integration policies was centred "on the individual responsibility [...]. Integration policies became not only strongly related to issues such as shared norms about the rule of law and the obligation to know the Dutch language and culture, but also to social problems of public order and crime. Integration policies became more assimilistic and immigration policies more selective" (Van Meeteren et al., 2013, p. 119). The main policy tool within the "new course" has been the civic integration tests. Although these tests had already begun in 1998, a number of successive modifications $(2006,2007,2008)$ extended their scope and considerably increased their difficulty. Migrants willing to travel to the Netherlands for family reunification, family formation (marriage), labour or other reasons, were obliged to pass a paid test in the Dutch embassy of their countries; a minimum knowledge of the Dutch language and Dutch society were necessary. With the 2007 modification, the same requirements were extended to migrants already in the national territory. They had to pay for their own integration courses and were given a certain time to pass the tests. In case of 
failure, administrative fines were applicable. As has been pointed out, these tests have become powerful tools to restrict migration (Garcés-Mascareñas, 2011).

\subsection{Spain as an Irregular Migration Context}

\subsubsection{Migration History and Contemporary Trends}

The transformation of Spain into an immigration country took place in the mid-1980s, after centuries of emigration history. This important event passed somewhat unnoticed by the public opinion and the government in those years (Izquierdo, 1996). When the Spanish government had to negotiate the conditions to join the European Union, a major concern at the bargaining table was the risk of a heavy outflow of workers towards the richer partners of the North. For this reason, the final agreement included a transitory norm that limited the circulation of Spaniards for some years. Contrary to all expectation, the entry of Spain into the European Union, on the first of January, 1986, did not mean an increase in emigration. Ironically enough, it was that year that the net flows changed sign and the inflows surpassed the outflows.

From that moment on, and for the next decade, Spain would experience a slow but continuous increase in migration numbers. These, nevertheless, would be far lower than those experienced by traditional European migration countries (Arango, 2010). It was in the last years of the past century, and especially in the first of the new one, that migration to Spain reached truly spectacular volumes, determining a radical and far-reaching change to the demographic structure of the receiving society.

The arrival of migrants was mainly sustained by a powerful demand for foreign workers which was itself determined by the booming economy (Aja \& Arango, 2006; Arango, 2005, 2010; Cachón, 2009; Cebolla \& González Ferrer, 2008). Although unemployment among nationals was not marginal, especially among young people, the segmented character of the labour market permitted a complementary integration of the newcomers. These were especially required in a number of specific sectors, in particular: construction, services, agriculture and personal services.

As regards the origin of migrants, the main fluxes arrived from East-Europe (Romania and Bulgaria), Latin America (Ecuador, Bolivia) and North and West Africa (Morocco). The main entry channels were visa overstaying and irregular border crossing. Asylum-seeker requests played a secondary role in comparison to other European countries (see Fig. 6.11) (González-Enríquez, 2009). Within the considered time lapse, the peak was reached in 2001, with 9489 requests. The years to follow, with the partial exception of 2007, saw permanent decrease.

In 2012, of a total population of 46,818,219 individuals, the foreign-born population in Spain counted 6,618,200 individuals, which represented 14.3\% (OECD). In 


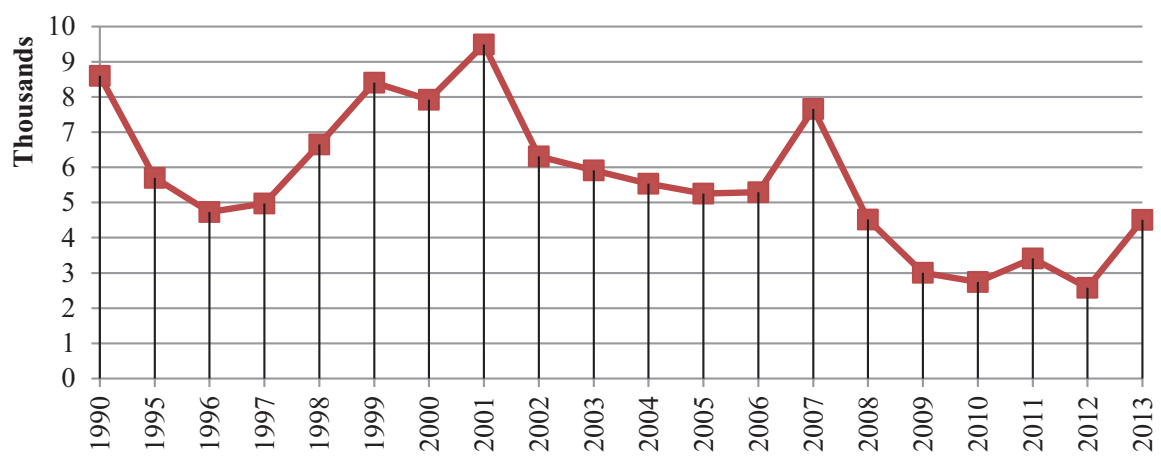

Fig. 6.11 Asylum-seeker requests. (Data from: OECD)

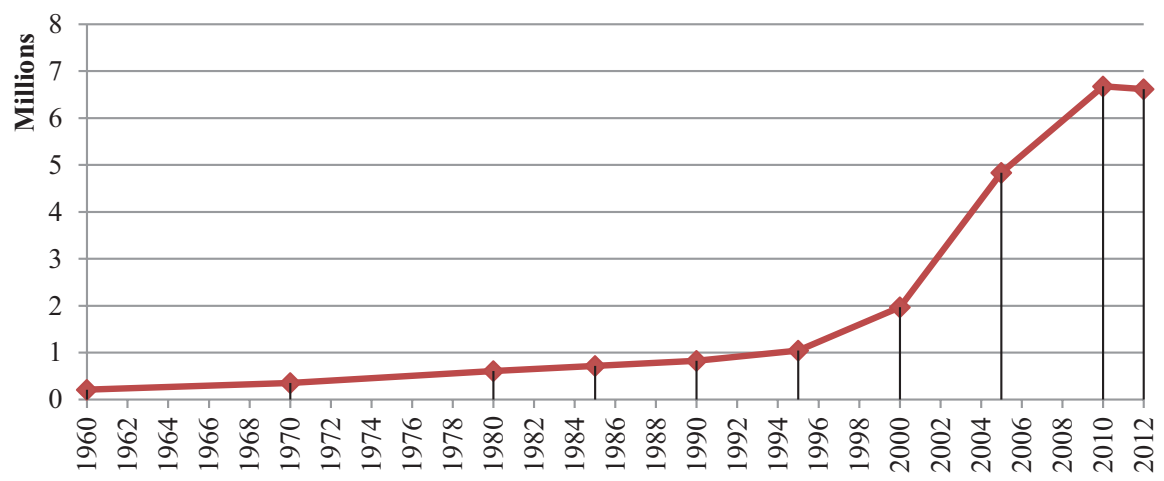

Fig. 6.12 Foreign-born population. (Data from: OECD)

order to have an idea of how fast and sharp the demographic change was, all one has to do is to recall that in 1995 , less than 20 years before, the foreign-born population counted 1,401,200 individuals which represented 2.6\% (see Fig. 6.12).

As regards the yearly inflow of new migrants during the 1999-2012 lapse (see Fig. 6.13), it is possible to clearly distinguish two phases. The first, between 1998 and 2007, was characterized by the continuous and formidable growth of annual entries. With the exception of the year 2003, in which the increasing trend slowed down, in all the other years new records were registered. The maximum was reached in 2007, when a little more than 900,000 new migrants entered the country. The second phase, which started in 2008 , was characterized by a decreasing trend. While the inflows remained sustained and exceeded 300,000 individuals per year, the change of sign was evident. In 2011, after 25 years of continuous growth, the immigrant population fell slightly, initiating a decreasing trend that persisted in the year to follow (Arango, Moya Malapeira, \& Oliver Alonso, 2014). 


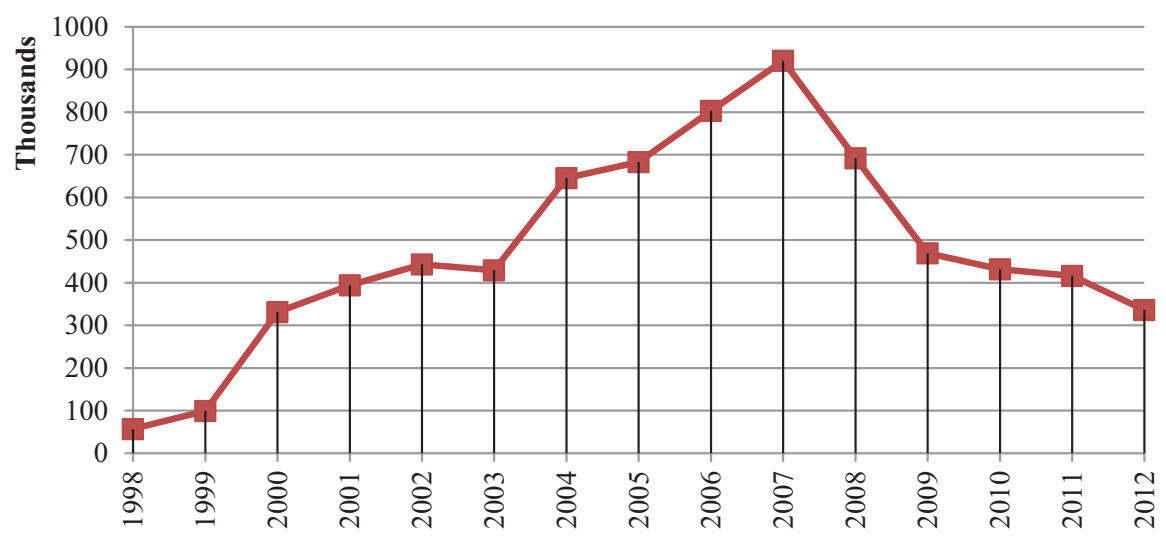

Fig. 6.13 Annual migration inflow. (Data from: OECD)

\subsubsection{Irregular Migration Estimations}

As pointed out by numerous scholars, the Spanish case provides a remarkably better possibility to elaborate irregular migration estimations than most of the other countries (Cachón, 2009; Cebolla \& González Ferrer, 2008; González-Enríquez, 2009; Recaño \& Domingo, 2005). This has been related to the strong incentive that irregular migrants have to register in the Municipal Records (Padrón Muncipal). This simple registration, which does not have any legal or administrative consequence, allows free access to most social services, such as, education for children or health care. The comparison between the total number of foreigners in the Municipal Register and that of foreigners with a valid resident permit (these include labour, study and asylum permits) allows one to obtain a fairly realistic estimation of the number of irregular migrants in Spain (G. Echeverría, 2010, 2014b).

As is possible to observe (see Fig. 6.14), also regarding the number of irregular migrants, two phases can be clearly distinguished. The first, between 2001 and 2005 , was characterized by the sustained growth of the irregular population. The peak was reached in 2005, when estimated irregular migrants surpassed 1,400,000 individuals. The second phase, from that year on, displayed a sharp decrease in irregular population in the first 2 years, and stabilization with a decreasing tendency in the years to follow. The last available data, from year 2010, indicated a population of roughly 400,000 irregular migrants (Echeverría, 2014b). Two factors that contributed to the substantial reduction of the stock of irregular migrants registered in 2006 and 2007 were: A. the massive regularization enforced by the Spanish government in 2005; B. the automatic regularization of Rumanian and Bulgarian migrants determined by the admission of both their countries into the European Union on the first of January, 2007 (Finotelli \& Arango, 2011; GonzálezEnríquez, 2009). 


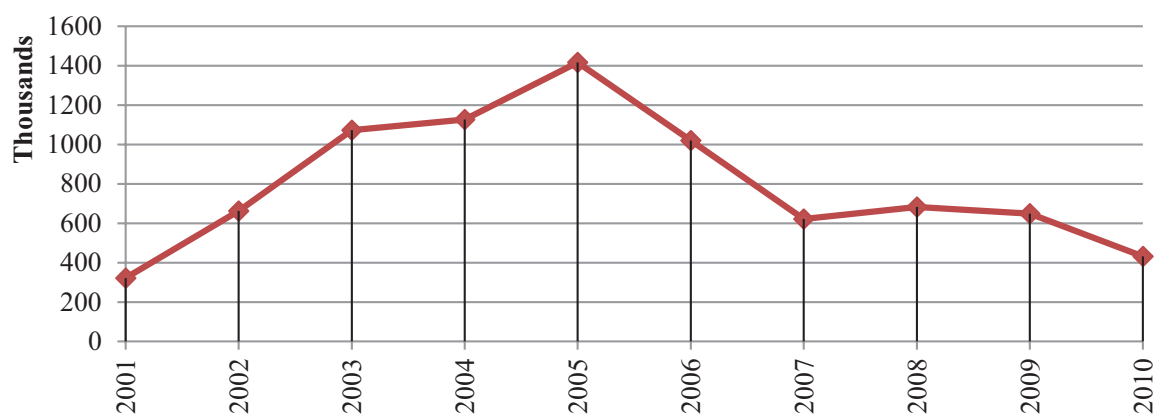

Fig. 6.14 Irregular migrants estimation. (Own elaboration, data from: Instituto Nacional de Estadística (INE) and Ministerio de Empleo y Seguridad Social (MESS)

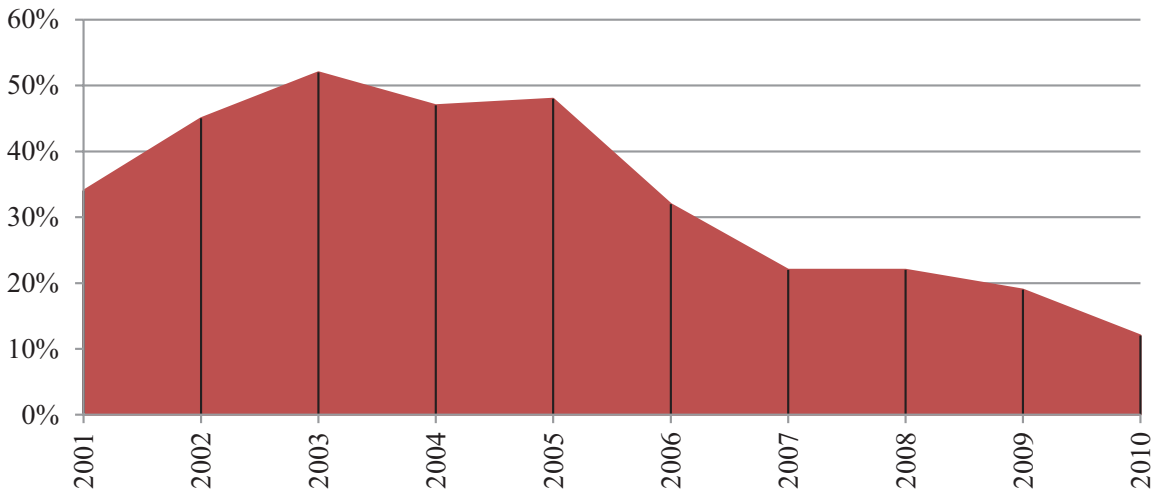

Fig. 6.15 Irregular migrant percentage over total foreign population (Own elaboration, data from: INE and MESS)

The share of the irregular population over the total foreign population (see Fig. 6.15) followed an increasing trend in the first years of the 2000s and reached its maximum in 2003, when it slightly exceeded 50\%. In 2004 and 2005, the proportion decreased somewhat, but remained substantially above $40 \%$. Also in this case, it is possible to clearly distinguish the combined effect of the 2005 and 2007 direct and indirect regularizations. In 2007, the irregular migration population accounted only for $20 \%$ of the total foreign population. The decreasing trend persisted in the years to follow. The last available data suggest that in 2010 the considered proportion had fallen to $12 \%$ (G. Echeverría, 2014b).

A number of studies have inquired into different aspects of the irregular migration population in Spain (Godenau, Hernández, \& Expósito, 2007; Martínez Veiga, 2003; Recaño \& Domingo, 2005; Van Nieuwenhuyze, 2009); a general overview of its main socio-demographic characteristics is available in Clandestino Report for the case of Spain (González-Enríquez, 2009). 


\subsubsection{Migration Regime}

The Spanish migration regime is relatively short-lived (Aja, 2009b; Aja \& Arango, 2006; Arango \& Finotelli, 2009; Arango \& Jachimowicz, 2005; Cachón, 2007, 2009; Cebolla \& González Ferrer, 2008). This is not surprising if it is considered that until 1986 Spain had been one of the main emigration countries in Europe.

The first comprehensive migration regulations were approved in 1984 (Asylum and Refugee Law) and in 1985 (Foreigners Bill). Both laws had to be approved as part of the agreements contracted by Spain in order to become a member of the European Union. This circumstance had a fundamental impact on the regulatory conception that informed the two provisions. The main concern of the European partners, which in the majority of cases had a long migratory history and a restrictive attitude towards migration, was to avoid Spain becoming the new entry-gate for massive inflows. Moreover, the high unemployment rates registered in the country suggested that no labour migration was needed.

The 1985's Foreign Bill (Ley Orgánica ${ }^{2}$ No. 7/1985) established a highly restrictive entry system for new migrants, the Regimen General (General Regime). The basic underlying principle was that before granting an entry permit to a migrant, a labour market check had to be carried out. Only if no native was available for the same position, could the migrant be hired and travel to Spain. In 1993, an additional mechanism was introduced, the Contigente (Entry Quotas). In this case, the administration, in agreement with the employer associations and the trade unions, had to establish each year a certain number of permits associated with available positions in the labour market to be offered to potential migrants. Neither of these channels ever worked properly. On the one hand, the Regimen General procedure was extremely complex and would have required a perfect coordination between the consular services abroad and the labour offices in Spain. On the other hand, also the Contigente required a complicated procedure and the pre-exiting agreement between the Spanish government and those of the potential migrants' countries. For this reason, as pointed out by Arango and Finotelli, this channel "never turned into an effective policy regulation instrument since it was simply used to legalize irregular migrants already living in Spain" (Arango \& Finotelli, 2009, p. 18).

During the 1990s, as the Spanish economy started to grow consistently and the demand for foreign labour increased, it became apparent that a migration regime "imported" from countries with very different migration histories and labour market structures, was to be highly dysfunctional. Although the unemployment rate was high among natives, the segmented characteristics of the labour market determined the simultaneous existence of a high demand for unskilled foreign work. However, the available entry channels were insufficient and could not efficiently meet such demand. The combination of narrow channels for legal migration, embryonic migration control systems (since immigration was so recent) and an increasing demand for migrants exemplarily translated into an "irregular migration model" (Izquierdo,

${ }^{2}$ From here on, LO. 
2009). Both for migrants and for employers, it was easier to achieve their respective goals independently of the channels enabled by the state.

As the alarm caused by the growing numbers of irregular migrants rose, a first major revision of the Foreigners Bill was approved in 2000 (LO No. 4/2000). The reform eliminated the Regimen General, reformed the Contigente and included the important decision to extend access to healthcare and basic education to all migrants without taking into consideration their administrative status. Despite these modifications, the entry regime remained largely ineffective and remained unable to satisfy the real necessities of the Spanish labour market (Arango \& Finotelli, 2009). The problem was not solved either by the successive reforms approved thereafter, LO No. 8/2000 and LO No. 14/2003.

As had been occurring since the 1980s, the only effective measure to reduce the continuously growing stocks of irregular migrants was the implementation of massive regularizations. These "extraordinary measures" were "the most useful way to "repair" a posteriori, the structural mismatches of the Spanish migration regime in which irregularity and informality were constantly feeding each other" (Arango \& Finotelli, 2009, p. 19). Between 1985 and 2005, the government approved six regularization processes (1985, 1986, 1991, 1996, 2000, 2001, 2005), which, altogether, rectified the administrative condition of 1,200,000 irregular migrants. The biggest regularization, called Normalisación (normalization), was ratified by the Socialist Party in 2005; this process alone involved more than half a million migrants. A prolific literature has analysed the characteristics, dimensions and consequences of these policy measures.

The 2005's regularization, however, was not just another episode of the wellknown story. On this occasion, the measure was intended as part of a wide-ranging revision of the whole migratory regime that had started a year before with the approval of the Regulation 2393/2004. The new approach comprised four main lines of action, which have been thoroughly analysed (Arango \& Finotelli, 2009; Cachón, 2009; Cebolla \& González Ferrer, 2008; González-Enríquez, 2009). The first goal was to create adequate entry channels for foreign workers. In this respect, the Regimén General was re-introduced with a simplified procedure. A Catalogue of Hard-to-find-Occupations had to be published by the administration every 3 months in agreement with the trade unions and employer associations. An employer, who wished to hire a worker for a job that was included on the list, did not require a negative certification as had happened before. Moreover, modifications were introduced to Contigente and a new visa for "job search" was introduced.

The second goal was to create a permanent mechanism to allow irregular migrants to regularize on an individual basis. To this end, the Arraigo was introduced. This scheme permitted migrants to get a residence permit if they were able to demonstrate either a pre-existing labour story (arraigo laboral) in Spain or their social integration (arraigo social).

The third goal was to improve external border control in order to reduce irregular entries. A number of measures were taken, in particular: A. tougher rules as regards visa policy (in order to reduce visa overstayers); B. the introduction of sophisticated border control systems (in particular the Sistema Integrado de Vigilancia Exterior, 
SIVE, in order to control the arrival of boats to the coasts); C. the development of bilateral agreements with the main sending countries (readmission and collaboration agreements).

The fourth goal was to reduce the attractiveness of the labour market and to make irregular residence more difficult by improving internal control policies. Two important measures were taken. On the one hand, the labour inspection agency was potentiated with more personnel and new strategies. This meant that the number of inspections per year was increased and their implementation was better targeted. On the other hand, a new emphasis was given to the repatriation policy. This implied more resources, newer and more efficient detention facilities, better identification systems, and agreements with origin countries.

A new reform of the Foreigners Bill was approved in 2009 (LO 2/2009) which was complemented by a new Regulation in 2011 (557/2011) (Aja, 2009a; Montilla, Rodríguez, \& Lancha, 2011). These provisions extended the rights of irregular migrants in a number of sectors. In particular, the right to assemble, to associate, to demonstrate, to unionize and to strike was recognized. The possibility for irregular migrants to obtain free education was extended until they were 18 years of age. It was recognized that all foreigners, including those with an irregular status, had a right to have free legal protection in the case of need. However, at the same time, new restrictions were introduced. The family reunification policy was revised. As for irregular migration, a number of provisions were adopted to discourage irregular residence and employment and to make expulsions more effective; in particular: new infractions; higher fines for employers, traffickers, facilitators and migrants; new repatriation procedures; longer administrative detentions (from 40 to 60 days).

An important change that affected irregular migrants was introduced in 2012. The Real Decree 16/2012 excluded the possibility for those migrants without a valid residence permit to access healthcare assistance unless in cases of urgency, serious illness or accident (Montilla \& Rodríguez, 2012).

\subsubsection{Economics, Labour Market and Underground Economy}

As can be observed in Fig. 6.16, the Spanish Gross Domestic Product (GDP), used here as a general indicator of the economic trends, shows two very different trends within the considered lapse of years. Between 1998 and 2008, on which the partial exception in 1999, 2003 and 2008, the economy markedly grew, registering positive variations that averaged 3\% per year. Between 2009 and 2012, on the contrary, the economy underwent a deep recession. In 2009, the GDP variation registered $-3.8 \%$; in the next 2 years, it averaged a $0 \%$ variation; a new drop followed in 2012, with a $-1.6 \%$ variation.

The labour market followed a similar trend. Two contrasting, very marked phases are distinguishable. Between 1998 and 2007, there was a spectacular increase in total employment. In less than 10 years, more than 6,500,000 new jobs were created. In contrast, between 2009 and 2012, an accelerated destruction of jobs took 


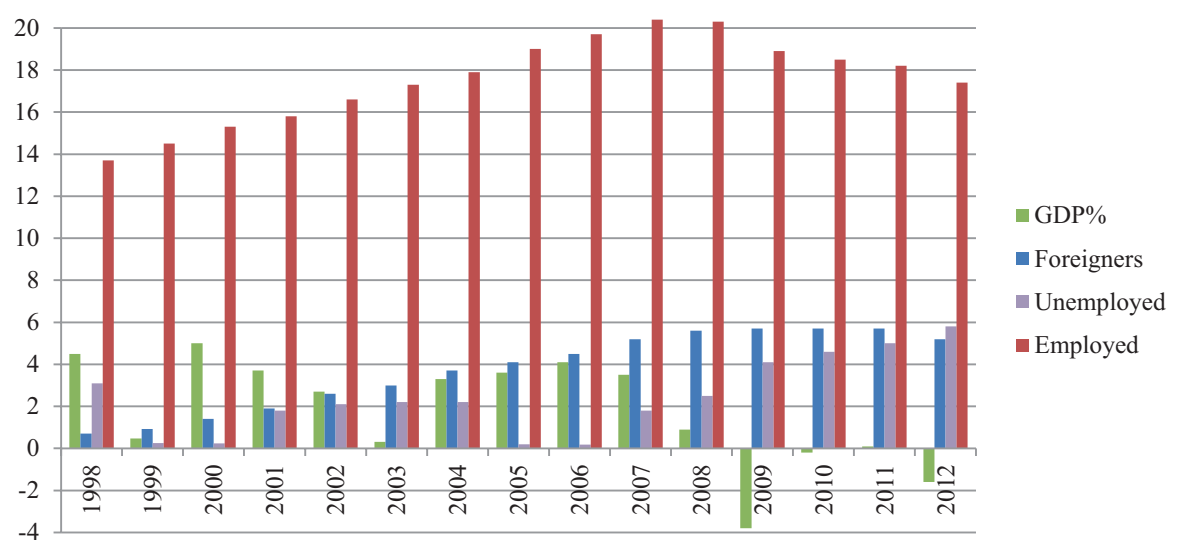

Fig. 6.16 GDP variation, employment, unemployment, migration. (Data from: Eurostat. GDP is expressed in annual variation; Foreigners, Employed and Unemployed are presented in millions per year)

place. The effects of the economic crises determined the loss of almost 3000,000 jobs in 5 year. Similarly to what was underlined in the discussion of the Dutch case, a direct, slightly delayed correlation with the GDP is observable. Yet, in the case of Spain, the effects of this relation appear to be much more accentuated (Finotelli \& Echeverría, 2017). As pointed out by Finotelli, this has to do with the high level of elasticity of the Spanish labour market, which makes it very sensitive to the GDP variations (Finotelli, 2012, pp. 11-14).

As regards unemployment, an inverse, slightly delayed, very marked correlation with the GDP is observable. In general (see Fig. 6.17), if compared with its European partners, high levels of unemployment have characterized the Spanish labour market. In 1998, almost $20 \%$ of the active population was unemployed. The effects of the economic boom radically changed this picture in the next 10 years. In 2007, the unemployment rate had fallen to $8.7 \%$. From that year on, however, the rate started to grow again, and progressively very quickly. In 2012, more than $24 \%$ of the active population was unemployed.

Concerning the occupation structure within the considered lapse of time (see Fig. 6.18), the Spanish labour market shows again two different phases. In the first, between 1998 and 2007, all occupations grew. However, the five sectors that created most new jobs were (International Standard Classification of Occupations - ISCO): Services and sales workers ( +1.3 million), Technicians and associate professionals (+1.3 million) Elementary occupations $(+1.1$ million), Craft and related trades workers (+one million), Professionals ( +1 million). In the next 5 years, while a total of almost 3000,000 jobs were lost, the distribution was uneven. The sectors where most jobs were lost were: Craft and related trade workers ( -1.4 million) Elementary Occupation ( -0.8 million), Technicians and associate professionals $(-0.6$ million), Plant and machine operators and assemblers ( -0.6 million) and Managers $(-0.6$ million). The Services and sales sector $(+0.7$ million $)$ and Professionals sector $(+0.4$ 


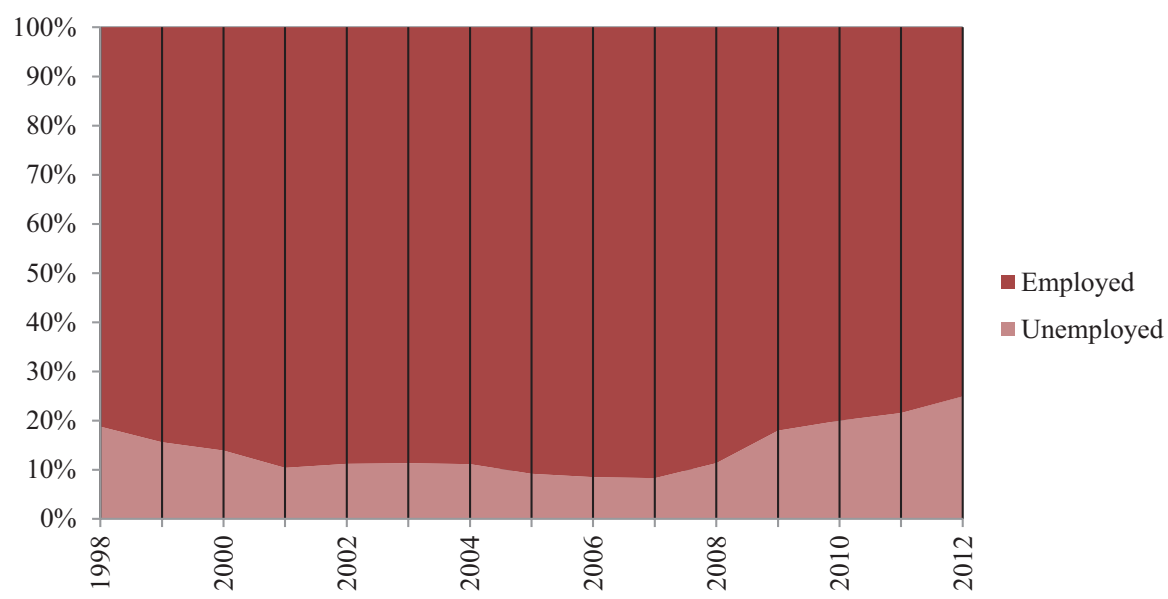

Fig. 6.17 Labour market structure. (Data from: Eurostat)

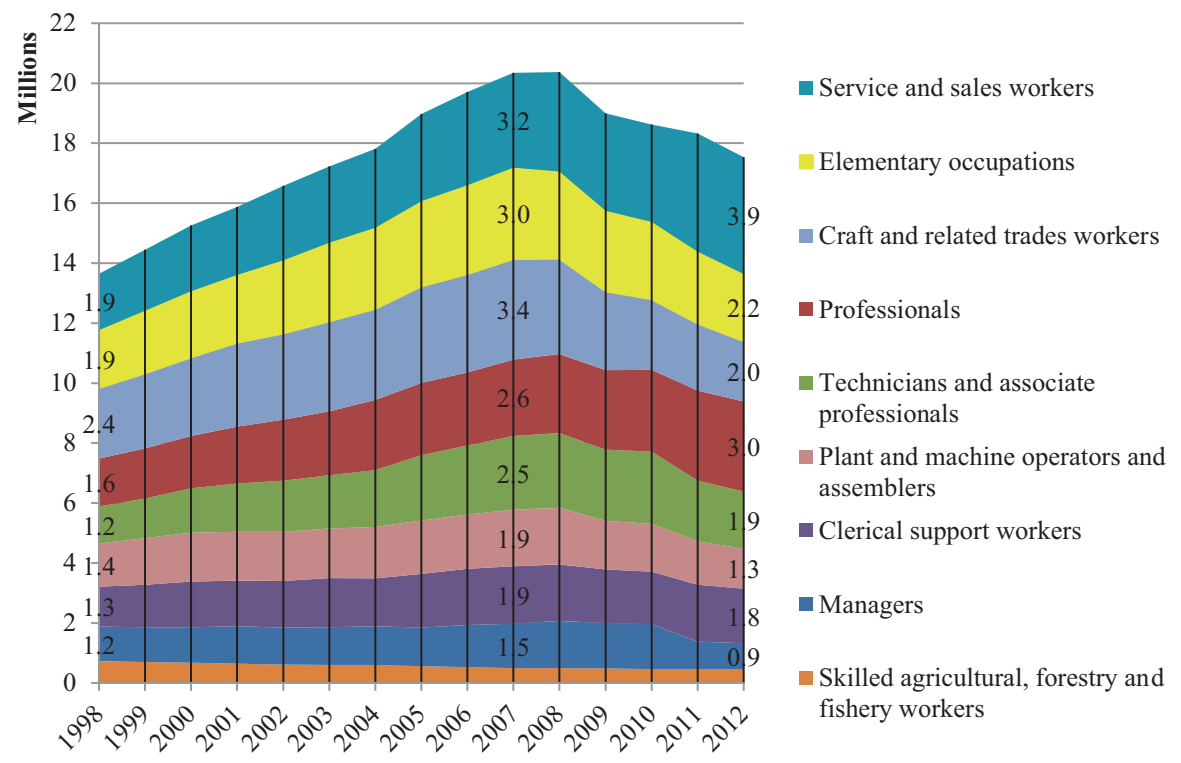

Fig. 6.18 Main occupations. (Data from: Eurostat)

million), on the contrary, continued to create new jobs. This analysis clearly shows the great importance played by unskilled sectors in the creation of jobs during the economic boom.

As regards the underground economy (see Fig. 6.19), the estimation provided by Schneider and his colleagues for Spain shows three different phases (Schneider et al., 2010, 2015). Between 1999 and 2003, the underground economy was stable, slightly above $22 \%$. In the years to follow, until 2008, a decreasing trend was 


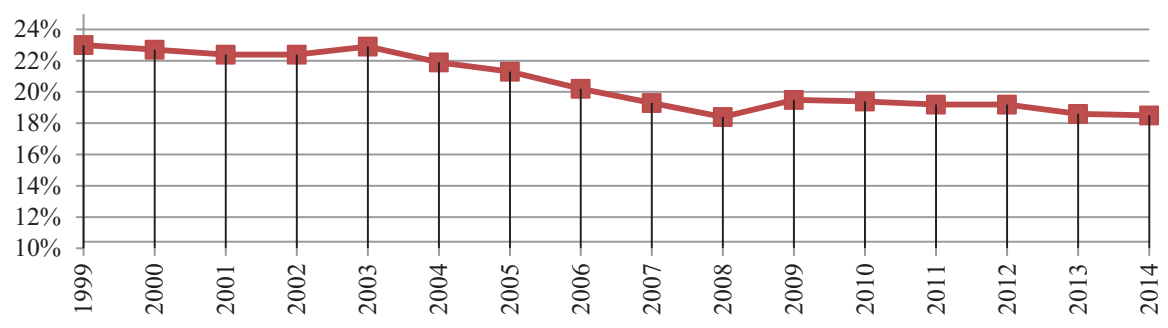

Fig. 6.19 Underground Economy. (Data from: Schneider et al., 2010, 2015)

observable that led to a fall of almost four points. From 2009 on, the rate has remained stable at around $19 \%$.

\subsubsection{The Welfare Regime in Spain}

Within the different welfare state clusters in Europe, the Spanish welfare state is usually placed under the heading of the so-called Southern or Mediterranean Model (Ferrera, 1996; Ferrera et al., 2000; Gal, 2010; Hemerijck, 2012; Hemerijck et al., 2006, 2013). Besides the similarity with the Continental Model, the salient traits of the countries pertaining to the cluster, which also includes Italy, Portugal and Greece, model, are: the development of national health services; an acute insider/ outsider distinction when it comes to social benefits; an emphasis on pension transfer in detriment to other social services; a stronger emphasis on the male breadwinner model combined with high levels of familiarism; weak or non-existent safety nets (Ferrera, 1996).

Beyond its intellectual interest, the long and on-going debate over the plausibility and usefulness of this fourth typology of welfare regime (Ferrera, 2008; Guillén, 2010; Guillén \& León, 2011; L. Moreno, 2001), in addition to the three originally proposed by Esping-Andersen (Esping-Andersen, 1990), evidences two issues: on the one hand, the mixed nature of welfare regimes usually included within the Southern Model and, on the other, the continuous and deep transformations that these regimes have undergone in the last few decades.

These two issues perfectly apply to Spain. The Spanish welfare regime has been defined as a "hybrid of models" (Rodríguez Cabrero, 2011, p. 33). Its orientation appears Bismarckian, in relation to the income transfers and the emphasis on pensions, and Beveridgean, in relation to its universal national healthcare system. Moreover, the continuous procedure of reforms that the regime has undergone since its first development in the 1970s, makes it even more difficult to use a single label.

In its origins, the Spanish welfare regime was strongly influenced by the characteristics of its traditional society and the country's late modernization. This signified that it had a number of distinctive features (Hemerijck et al., 2013, pp. 33-34). First, there existed a pronounced insider/outsider cleavage between workers in the "core/ 
regular" sectors and workers in the "peripheral/irregular" sectors, the unemployed, family dependents or the poor. The former could rely on a generous system of social insurance, especially centred on pensions, while the latter were largely unprotected. Second, there was the paramount importance of families as the primary location of welfare production and economic redistribution (between generations and gender). In this context, the role of women was fundamental, determining a low level of female participation in the labour force. Third, there existed a highly regulated labour market, which fostered a marked dualism between permanent and temporary contracts. Fourth, social assistance programs were underdeveloped and weak which meant that there were comparatively higher levels of poverty (Rodríguez Cabrero, 2011, p. 33).

In the 1980s and the early 1990s, the Spanish welfare regime underwent a number of reforms that substantially modified its structure and scope. The Socialdemocratic model inspired the orientation of these interventions. The leading idea was that "subjective rights to health and education, financed through taxation" would "contribute to lessening inequalities and enhancing female access to the labour market" (Rodríguez Cabrero, 2011, p. 22). The main advancements were: the introduction of a universal education system $(1985,1990)$; the institution of a universal health care service $(1985,1990)$; the universalization of the pension system (1990); the introduction of regional minimum income Schemes (1989-1994).

Nevertheless, the economic crisis and the rapid rise in unemployment in the early 1990s, put the state budget under heavy pressure and forced the initiation of a process of welfare recalibration that, through a number of successive waves, has lasted until today. What has also contributed to this process was the concurrent Europeanization of social policy that implied the necessity to extend certain rights and to restrain expenditure.

In the important Toledo Pact (1995) "it was agreed that pensions and unemployment insurance benefits were to remain financed out of social contribution, but all the other non-contributory and social assistance benefits would come to be financed out of taxation" (Hemerijck et al., 2013, p. 35). The main lines of intervention in the years to follow have been four. A. Several measures were introduced to make the labour market more flexible and to balance the social protection between permanent and temporary workers. B. The social spending went through a process of rationalization and general reduction. A means-tested social assistance scheme (Renta Activa de Inserción) was implemented as well as the activation and formation of programs for the unemployed. Moreover, selective outsourcings and privatizations took place in the public welfare services. C. On the institutional level, the welfare services, including healthcare, education, care services were increasingly decentralized. D. Important measures were implemented to favour gender equality and the reconciliation of work and family life (Rodríguez Cabrero, 2011).

The effort to modernize and recalibrate the Spanish welfare state has been severely affected by the economic crisis that has affected the country since late 2007. The general budgetary cuts imposed by the economic situation signified a reduction of social expenditure, the termination of many social programs, a further 
flexibilization of the labour market, and a revision of the pension schemes (Hemerijck et al., 2013, pp. 34-37).

Three features characterize the contemporary Spanish welfare regime: first, the importance of the social security contributory system and the redistributive pension scheme; second, the existence of a universal system of education and healthcare not linked to labour participation; third, the still uneven and fragmentary development of the social assistance service. On the whole, then, as pointed out by Rodriguéz Cabrero, the Spanish welfare state has become "a consolidated medium-sized mixed welfare state with social spending levels below the EU-15 mean" (Rodríguez Cabrero, 2011, p. 25). Notwithstanding the important advancements in the last two decades, "it is the Bismarckian strand that still dominates the system as a whole; that is to say, what position in the labour market still counts more than citizenship, need or exclusion" (Rodríguez Cabrero, 2011, p. 34).

For the immigrant population, these characteristics of the Spanish welfare state have produced ambivalent results (J. Moreno \& Bruquetas, 2012). On the one hand, universal access to education, healthcare and other social services for migrants, including those with an irregular status, has been exceptionally inclusive. Yet, access to healthcare was eliminated in 2012. On the other, the importance of the social security model and the fragmentary development of social assistance programs, have certainly be an element of weakness, especially considering the high levels of immigrant unemployment.

\subsubsection{Politics, Public Opinion, Migration}

Although definitely recent in the history of Spain, the migration phenomenon has strongly impacted its society. Statistics allow us to clearly measure the magnitude and speed of this change. In the lapse of two decades, the country passed from being a net emigration sender to being the second largest recipient of immigrants in the world, just behind the United States. In the decade of the 2000s, new arrivals reached extraordinary numbers. In 10 years the foreign population gained over five million individuals and their share of the total population grew from just under $4 \%$ to more than $14 \%$.

While this spectacular transformation has certainly raised the attention of the public opinion and has materially changed the social landscape in many areas of the country, it has not led to significant anxiety or backlash. As pointed out by Arango: "Immigration was seen as a requirement of the labour market, an outcome of the economic progress, and perhaps even a sign of modernity" (Arango, 2013, p. 3). In his analysis, three arguments are proposed to support this claim. On the one hand, public opinion surveys have generally shown low, although slowly rising, levels of concern (Cea D’Ancona, 2011; Cea D’Ancona \& Valles Martínez, 2013). There have been punctual moments in which the attention has risen, like during the Cayucos crisis (Cayucos are the small boats used by irregular migrants to reach the Spanish coasts) in 2006, but these have been rather exceptional. On the other hand, 
there has been no politicization of the issue. In Spain, until this day, no xenophobic or anti-immigration political party has obtained noteworthy consensus either at a national or at a regional level. The only exception, Plataforma for Catalunya, has not had any representatives at provincial, regional or national level. More in general, no party has used the anti-immigration discourse as part of its electoral strategy. Finally, and in connection to the previous point, "immigration policies have tended to be open, and integration efforts sustained and comprehensive" (Arango, 2013, p. 4). The efforts of the Spanish government, in contrast to what has been the general trend at a European level, have not included shutting down entry channels for migration. Instead, they have tried to improve the legal channels for immigrant workers and to establish permanent mechanisms for individual regularization (Arango, 2013, pp. 3-5).

As for integration policies, the Spanish government has shown strong commitment to immigrant integration (for a discussion of the different stands of the integration policy, see: Aja, Arango, \& Oliver Alonso, 2012). Integration plans have been gradually developed at a national, regional and municipal level since the 1990s. Important consultative institutions, such as the Permanent Observatory for Immigration and the Forum for the Social Integration of Immigrants, have been created. In particular, the Forum, composed of nongovernmental organizations, immigrant associations, trade unions, employers' federations and the administration, has played a key role in orientating integration policies. The general orientation of integration policies has focused on the social and labour inclusion of the newcomers. Although there have been debates on the issue, until this day the Spanish approach has not followed the expanding trend to ask immigrants to pass language or civic knowledge tests.

Many observers expected that the positive attitude towards migration would have been negatively affected by the economic crisis. The impact of the economic crisis was indeed especially severe in Spain, and affected dramatically the immigrant population. Yet, as underlined by Arango, this circumstance "has not significantly altered social attitudes towards immigration, and immigration and integration policies have remained basically unchanged until now" (Arango, 2013, p. 6). Modifications to the migration regime (2009 and 2011), have not significantly altered liberal admission policies. Integration policies have been severely affected by the budgetary cuts introduced by the government at all levels; however, there have not been ideological reorientations or restrictive attitudes (Arango et al., 2014). An important exception to this generally preservative trend, was the approval in 2012 of a legislative decree which excluded irregular migrants, with certain exceptions (minors, pregnant women and emergency cases) from having the possibility to access public healthcare. Nevertheless, the application of this modification has encountered widespread social opposition and many regions have refused to operate it.

Arango has proposed three explanations for this generally positive attitude of the public and of the political world towards migration (Arango, 2013, pp. 9-12). On the one hand, the relative novelty of immigration to Spain and its high rate of labour participation have, for the moment, limited social conflicts. On the other, the pecu- 
liar historical and political evolution of Spain and, in particular, the recent regaining of democracy in the late 1970s, has contributed to generating a majoritarian political culture strongly influenced by democratic, egalitarian and universalist values. Finally, the absence of a militant national identity, motivated both by the multinational character of the country and the negative association of nationalism with the Franco regime, has inhibited ideas or feelings of immigration as a cultural threat.

\subsection{Conclusion: Assessing Contextual Differences}

\subsubsection{Migration History and Contemporary Trends}

Figure 6.20 shows an important difference between the Netherlands and Spain with regard to their immigration history. While the former is considered an old country of immigration, where second and third generations of migrants have grown up, the latter has a recent, although faster, migration history.

The Netherlands had a consistent immigrant population already in the 1960s, when it represented $4 \%$ of the total population. After a slight reduction in the 1970s, the share started to rapidly grow. In 1990, $8 \%$ of the population was born abroad. From that moment on, this share constantly rose, yet at a slower rate. In 2012, this was slightly below $12 \%$.

In Spain, instead, the immigrant population remained under 2\% until the 1990s. From that moment on, and especially after 1998, however, a spectacular increase took place. In 10 years, between 2000 and 2010, the immigrant population passed from $5 \%$ to above $14 \%$.

Also regarding the recent immigration trends, the Netherlands and Spain display a very different picture (see Fig. 6.21). While fluxes to the former have maintained relatively stable averaging 90,000-100,000 new entries per year, the latter has experienced a "prodigious decade" (Arango, 2010, p. 54) of immigration.

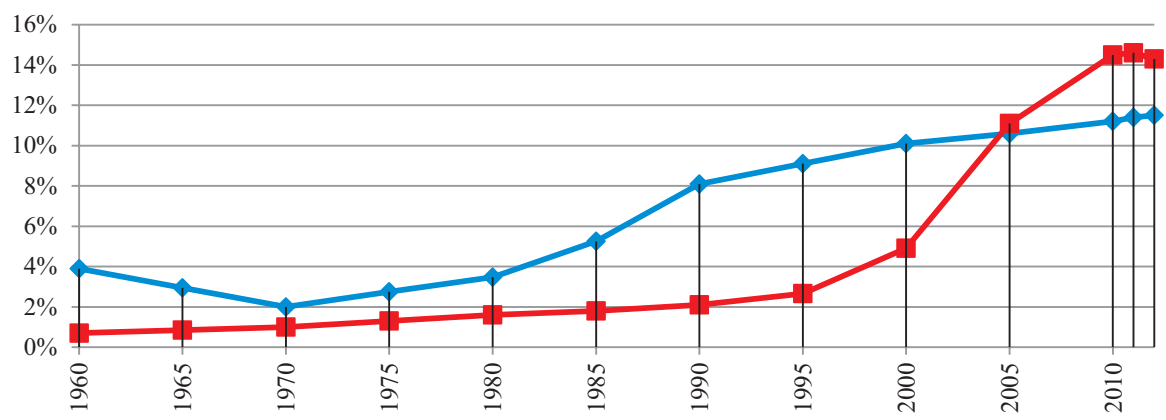

Fig. 6.20 Share of immigrant population over total population (Data from: OECD). Spain in Red, Netherlands in Light Blue 


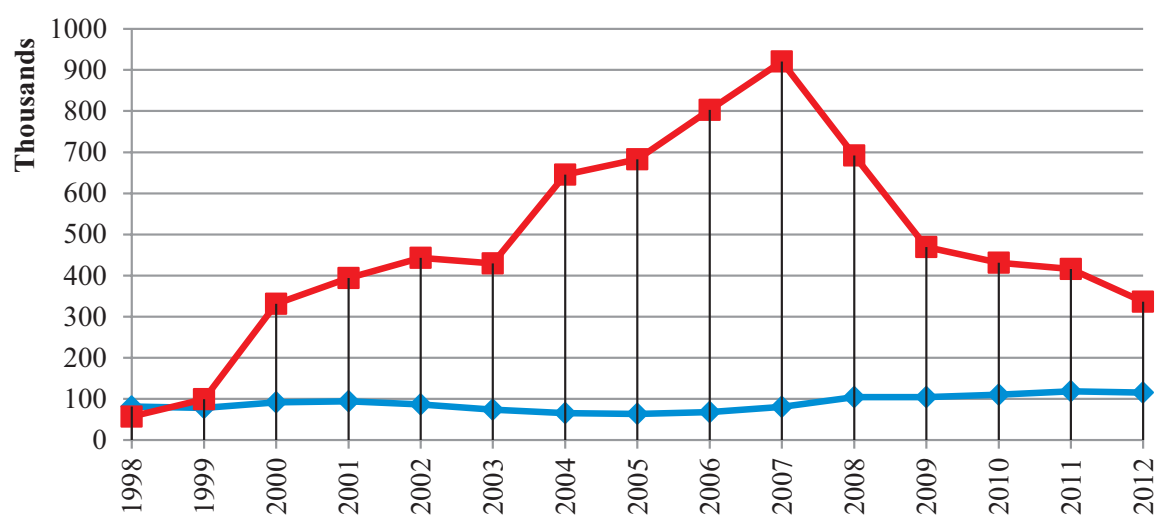

Fig. 6.21 Inflow of foreign population (1998-2012) (Data from: OECD). Spain in Red, Netherlands in Light Blue

\subsubsection{Irregular Migration Estimations and Trends}

The available estimations of irregular migration for the Netherlands and Spain in the decade of the 2000s display important differences regarding both their magnitude and trend (see Fig. 6.22). The maximum share of irregular migrants over the total foreign population was reached in the Netherlands in 2002 when it represented $30 \%$. From that year on, a gradual but continuous reduction has taken place, and, in 2009 , irregularity counted only for $15 \%$. In Spain, it is possible to distinguish two different phases. Until 2005, irregular migration had a growing trend and was a huge phenomenon. The peak was touched in 2003 when the share rounded 50\%, just like in the next 2 years. Between 2005 and 2007, there was a reduction of the stock of irregular migrants of almost 30 points, certainly the effect of the regularization of 2005 and the automatic regularization of Rumanians and Bulgarians in 2007. In years to follow, irregular migration in Spain has stabilized and appears to be slowly falling.

\subsubsection{Migration Regime}

In Table 6.1, a synoptic comparison of the actual migration regimes in the Netherlands and Spain is presented, with a specific focus on those elements that directly or indirectly affect the irregular migration phenomenon. Although in both countries legislation regarding migration has been continuously evolving, it is important to make a distinction as regards the extent of the changes in the period of our concern (1998-2013). While in the Netherlands, a number of modifications were introduced, it is possible to say that the basic normative model has been the same. In Spain, on the contrary, a crucial revision of the normative model took place 


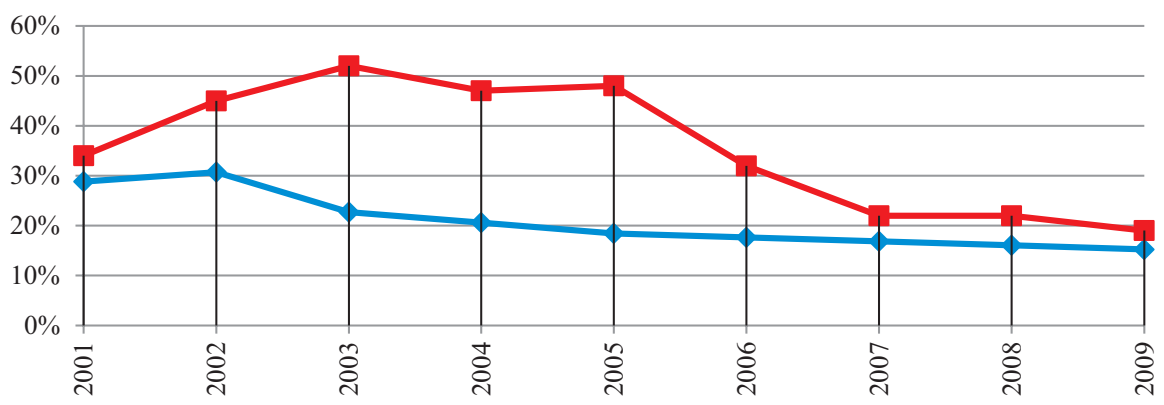

Fig. 6.22 Irregular migration share over total foreigners. (Own elaboration, data from: INDIAC NL EMN NCP 2012, Eurostat, INE, MESS). Spain in Red, Netherlands in Light Blue

in 2004, so a clear distinction is possible between the period before and after that year.

As regards the actual migration regimes, at least as they appear on paper, and focusing on those aspects especially important in relation to irregular migration, three fundamental differences stand out between the Netherlands and Spain.

Firstly, there is an important difference concerning the available channels for legal entry. Considering labour migration for unskilled-workers, the Netherlands has a generally (there are limited exceptions) very strict, labour-check based, language and civic test limited admission policy. Spain has a flexible, labour-demand based admission policy. As for asylum policy, the Netherland has historically had generous, open policies with high degrees of demand acceptance (yet, this policy has become increasingly strict since the 2000s); Spain has historically had a very restrictive asylum policy with low numbers of demand acceptance.

Secondly, the Netherlands has had an exceptionally limited extraordinary regularization policy and has no permanent regularization schemes; Spain adopted recurrent, massive extraordinary regularization processes until 2005 and since 2004 it has had a permanent regularization scheme at an individual level.

Thirdly, the two countries have had very different approaches to internal migration control policies. In this respect, however, especially since 2005, Spain has been gradually moving in a direction closer to the Dutch one. In the Netherlands, since the late 1990s, there has been a comprehensive policy to dissuade irregular residence and work, and to enhance repatriations. The three pillars of this strategy have been: the exclusion of irregular migrants from social services and, in particular, from healthcare; tougher labour market controls (more inspections, assessing control responsibility to employers, higher fines); the improvement of identification technologies, detention facilities and re-admission agreements to improve expulsions.

In Spain, a wide-ranging policy to dissuade irregular residence and work through internal controls has been incrementally constructed only since 2004. The pillars of this strategy have been: the toughening of labour market controls and the improvement of expulsions policies. Contrary to the Dutch case, no exclusion policy was 
Table 6.1 Synoptic comparison: migration regime and irregular migration

\begin{tabular}{|c|c|c|c|}
\hline \multirow{2}{*}{\multicolumn{2}{|c|}{ Irregular migration status }} & Netherlands & Spain \\
\hline & & Not a criminal offence & Not a criminal offence \\
\hline \multirow[t]{6}{*}{$\begin{array}{l}\text { Legal Entry } \\
\text { Channels }\end{array}$} & \multirow[t]{5}{*}{ Labour migration } & $\begin{array}{l}\text { a. Only if a Dutch or } \\
\text { EU job seeker is not } \\
\text { available. }\end{array}$ & $\begin{array}{l}\text { a. Individual. If the job is } \\
\text { included in a shortage list, an } \\
\text { employer can directly make an } \\
\text { offer and the job seeker can } \\
\text { apply for a visa (Regimen } \\
\text { General). }\end{array}$ \\
\hline & & $\begin{array}{l}\text { b. Temporary work } \\
\text { permit + temporary } \\
\text { residence permits } \\
\text { required before } \\
\text { leaving home country. }\end{array}$ & $\begin{array}{l}\text { b. Collective. Group } \\
\text { recruitment, for specific jobs, } \\
\text { from countries with a bilateral } \\
\text { agreement (Contigente). }\end{array}$ \\
\hline & & $\begin{array}{l}\text { c. Special schemes for } \\
\text { large companies. }\end{array}$ & $\begin{array}{l}\text { c. Job search visa. Visas are } \\
\text { granted to job seekers for } \\
\text { specific sectors. }\end{array}$ \\
\hline & & $\begin{array}{l}\text { d. Special rules for } \\
\text { highly-skilled } \\
\text { migrants. }\end{array}$ & $\begin{array}{l}\text { d. Special rules for highly- } \\
\text { skilled migrants. }\end{array}$ \\
\hline & & $\begin{array}{l}\text { Civic and language } \\
\text { test required. }\end{array}$ & $\begin{array}{l}\text { No civic and language tests } \\
\text { required. }\end{array}$ \\
\hline & Asylum seekers & $\begin{array}{l}\text { Generous policy, high } \\
\text { numbers. }\end{array}$ & Limited policy, low numbers. \\
\hline \multirow{10}{*}{$\begin{array}{l}\text { Regularization } \\
\text { Policy }\end{array}$} & \multirow{9}{*}{$\begin{array}{l}\text { Extraordinary / } \\
\text { Massive }\end{array}$} & $1975(15,000)$ & $1985-86(23,000)$ \\
\hline & & 1979 (1800); & $1991(110,000)$ \\
\hline & & $1991(2000)$ & $1996(22,000)$ \\
\hline & & 1999 (1800); & $2000(152,207)$ \\
\hline & & \multirow[t]{4}{*}{$2007(27,500)$} & 2000 re-examination $(36,013)$ \\
\hline & & & $2001(24,352)$ \\
\hline & & & $2001(157,883)$ \\
\hline & & & $2005(578,375)$ \\
\hline & & Total: 48,100 & Total: $1,103,830$ \\
\hline & $\begin{array}{l}\text { Permanent / } \\
\text { individual }\end{array}$ & Not available & Available (Arraigo) \\
\hline \multirow[t]{4}{*}{ Naturalization } & \multirow[t]{2}{*}{ Through residence } & \multirow{2}{*}{$\begin{array}{l}5 \text { years of legal } \\
\text { residence, proficiency } \\
\text { in Dutch, knowledge } \\
\text { of Dutch society } \\
\text { (citizenship tests) }\end{array}$} & 10 years of legal residence. \\
\hline & & & $\begin{array}{l}2 \text { years of legal residence for } \\
\text { citizens of Latin American } \\
\text { countries, Andorra, the } \\
\text { Philippines, Equatorial Guinea } \\
\text { or Portugal }\end{array}$ \\
\hline & \multirow[t]{2}{*}{ Through marriage } & With a Dutch citizen. & With a Spanish citizen. \\
\hline & & $\begin{array}{l}\text { With a EU-country } \\
\text { citizen }\end{array}$ & With a EU-country citizen. \\
\hline
\end{tabular}


Table 6.1 (continued)

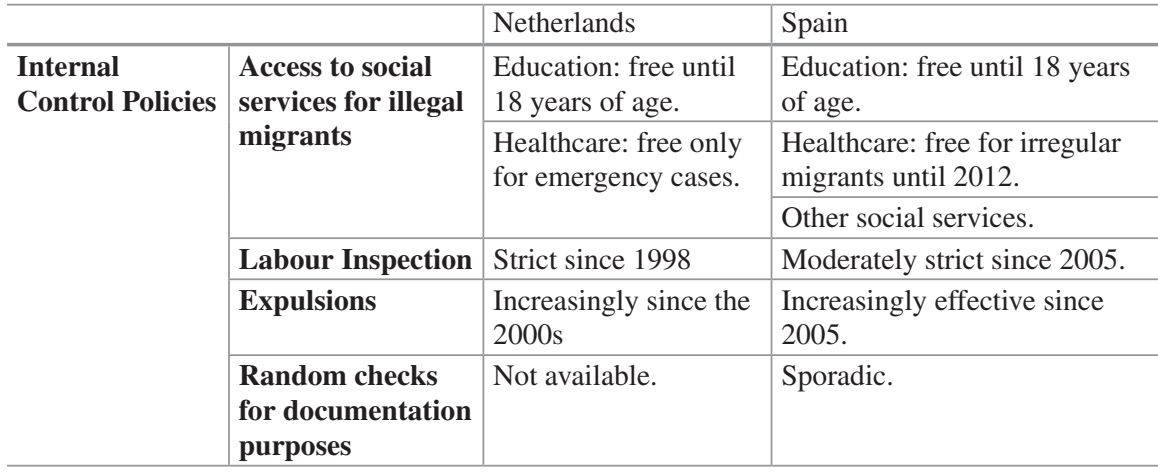

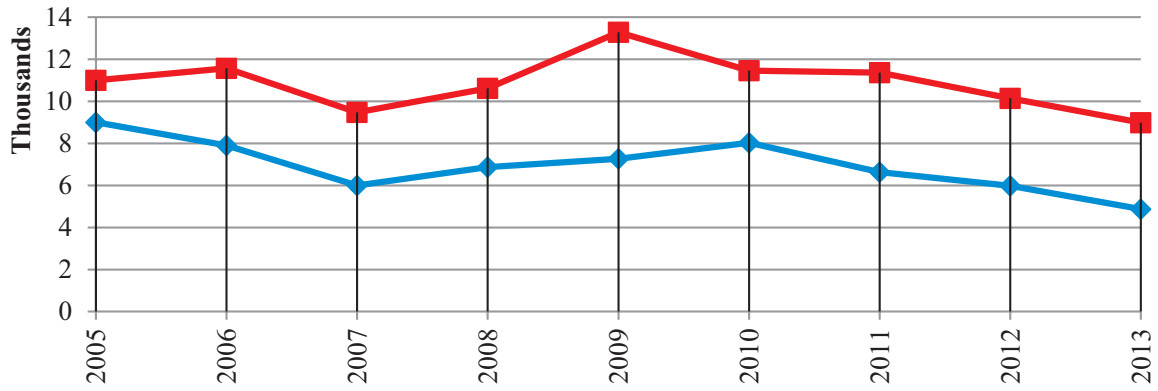

Fig. 6.23 Expulsions (Data from: NL (Data for Netherlands: 2005-2007, Leerkes and Broeders 2010, 2013; 2008-2013, Ministry of the Interior. Data for Spain: Ministerio de Interior). Spain in Red, Netherlands in Light Blue

enforced until 2012 and irregular migrants were able to freely access the public healthcare system and other social services.

Focusing on the efficacy of the expulsion policy, the available data (see Fig. 6.23), show similar trends between the two countries and moderately higher numbers for Spain. If the number of expulsions and the estimated irregular migrant population is considered, with the available data, a direct comparison is only possible for years 2005 and 2009. In 2005, the expulsion rate was $6.9 \%$ in the Netherlands, and $0.7 \%$ in Spain; in 2009, $7.4 \%$ and $2.0 \%$ respectively.

\subsubsection{Economics, Labour Market and Underground Economy}

As one can observe (see Fig. 6.24), the GDP of the two countries, between 1998 and 2013, shows different trends in the first years, until 2006, and a more similar picture in the years after that. In particular, the Spanish economy had an outstanding performance between 1997 and 2007 with yearly increases constantly above 3\%. In the 


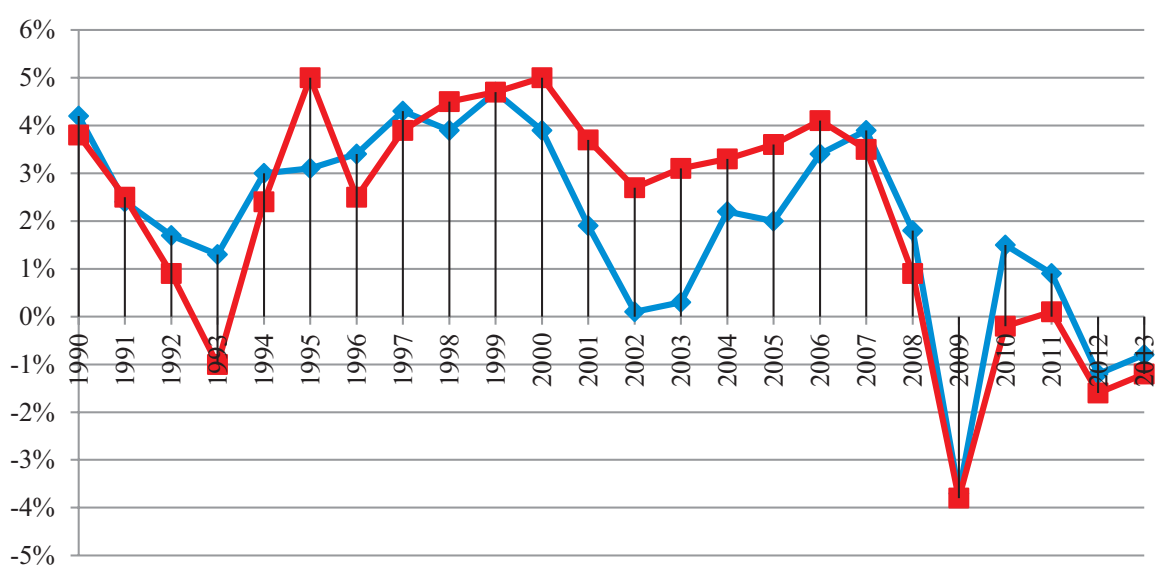

Fig. 6.24 GDP annual variation (Data from: OECD). Spain in Red, Netherlands in Light Blue

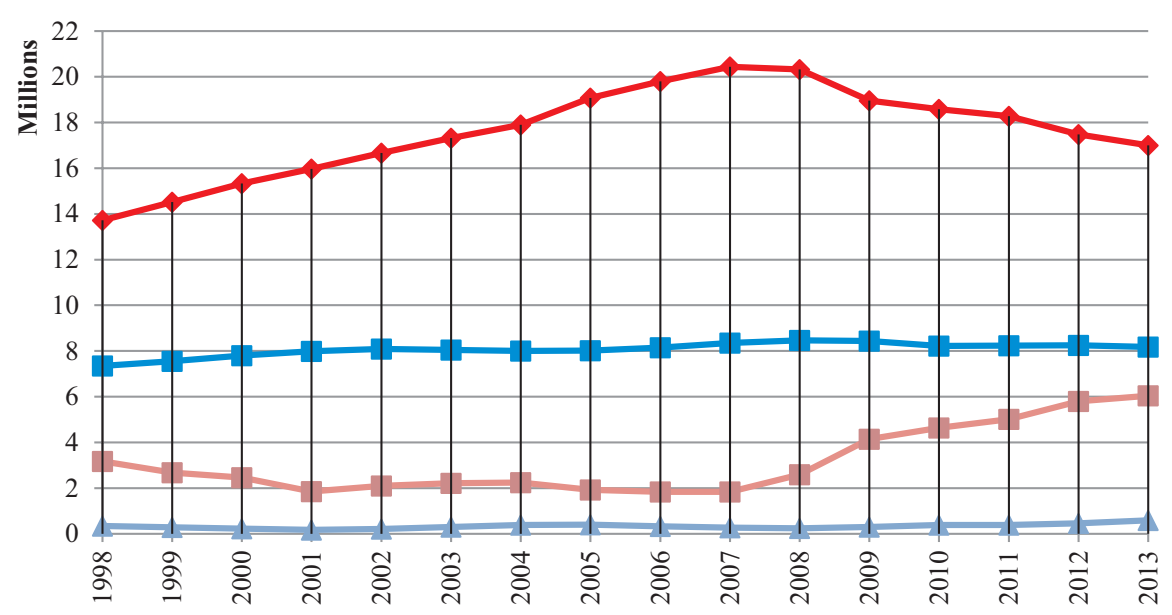

Fig. 6.25 Total employment and total unemployment (Data from: OECD) Spain in Red, Netherlands in Light Blue

same years, the Dutch economy had a much more ambivalent performance, especially in 2002 and 2003, when the GDP stagnated. The effects of the economic crisis struck the two economies severely in 2009. From that year on, the Netherlands had a slight recovery in 2010 and 2011, but the economy receded again in 2012 and 2013; the Spanish GDP, in contrast, never turned positive and was strongly affected by the new recession in 2012 .

Considering the labour market (see Fig. 6.25), the pictures of the two countries are very different. The Netherland had a very stable tendency. Employment grew slightly, while unemployment had little variations. Spain, on the contrary, created more than 6.5 million new jobs between 1998 and 2008. Almost half of those, how- 


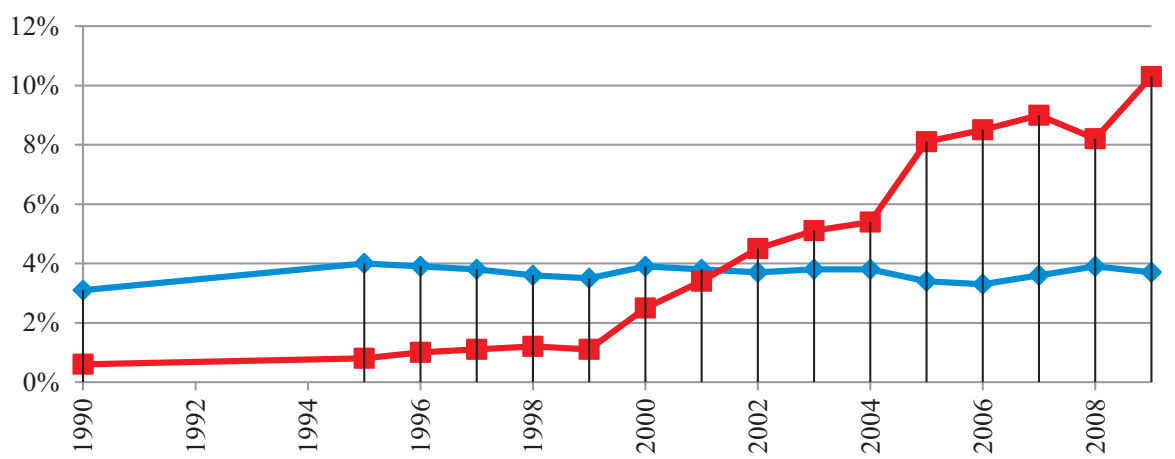

Fig. 6.26 Stocks of foreign-born labour (Data from: OECD). Spain in Red, Netherlands in Light Blue

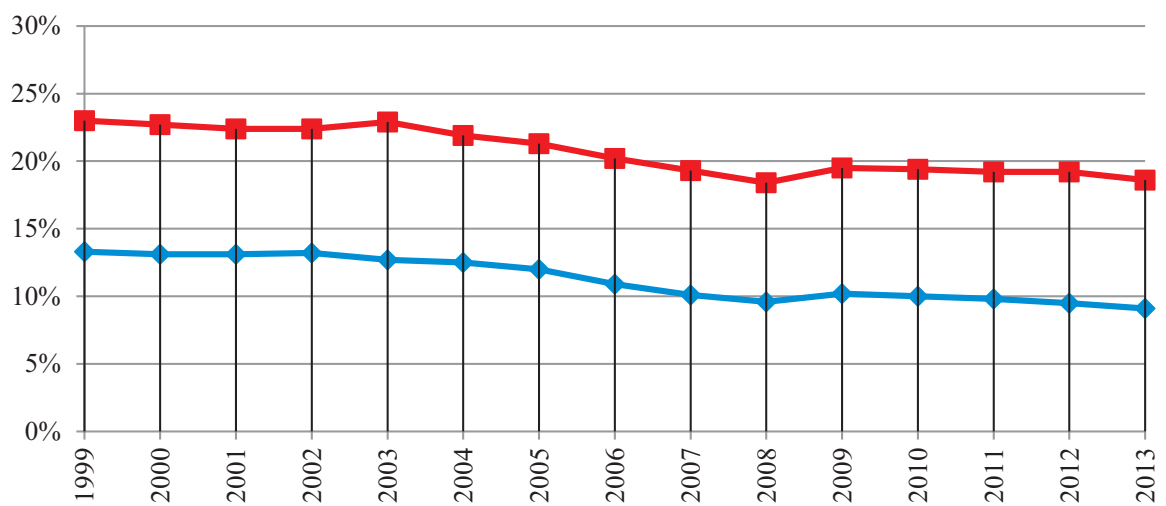

Fig. 6.27 Underground economy (Data from: (Schneider et al., 2010, 2015). Spain in Red, Netherlands in Light Blue

ever, were destroyed during the years of the economic crisis. Unemployment followed a similar trend, yet the effects of the crisis were even more marked. Between 2007 and 2013, almost four million individuals were registered on the unemployment lists.

In Fig. 6.26 it is possible to observe the significant relevance that foreigners played in the expansion of the Spanish labour market. While in the Netherland the share of foreign workers remained stable, in Spain between 1999 and 2009 it passed from around $1 \%$ to more than $10 \%$.

The underground economy followed a similar slowly-decreasing trend in both countries (see Fig. 6.27). The size of the phenomenon, nevertheless, is significantly different. In Spain the shadow economy on average was $10 \%$ greater than in the Netherlands.

These data (GDP trends, employment and unemployment, foreigners in the labour market, shadow economy size) combined with those previously analysed on 
the different sectorial structure of the two labour markets (with a marked low-skilled orientation of the Spanish one) reasonably suggest that the Spanish economy has been much more attractive for irregular migrants that the Dutch one.

\subsubsection{Welfare Regime}

The Dutch and Spanish welfare states were both originally placed under the heading of the so-called Conservative welfare states (Esping-Andersen, 1990). It was in relation to the important differences existing between the northern and southern European countries pertaining to this cluster, of which the Netherlands and Spain are each paradigmatic examples, that Ferrera, in 1996, proposed the need of a fourth cluster of welfare states, the Southern or Mediterranean one. What the interesting and on-going scholarly debate about the pertinence of this new category indicates is that the existing differences are all but marginal.

Comparing the Dutch and Spanish welfare states, a first element of difference is purely quantitative. As one can observe (see Figs. 6.28 and 6.29), considering both the total expenditure per head and this as a percentage of the GDP, the Netherlands spent constantly and considerably more than Spain did, although there was a slow process of convergence.

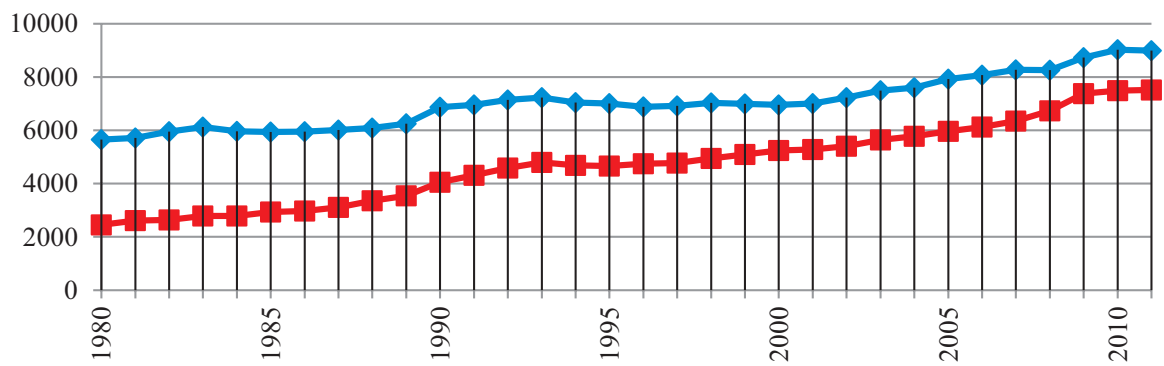

Fig. 6.28 Social expenditure per head at constant prices in US dollars (Data from: Eurostat). Spain in Red, Netherlands in Light Blue

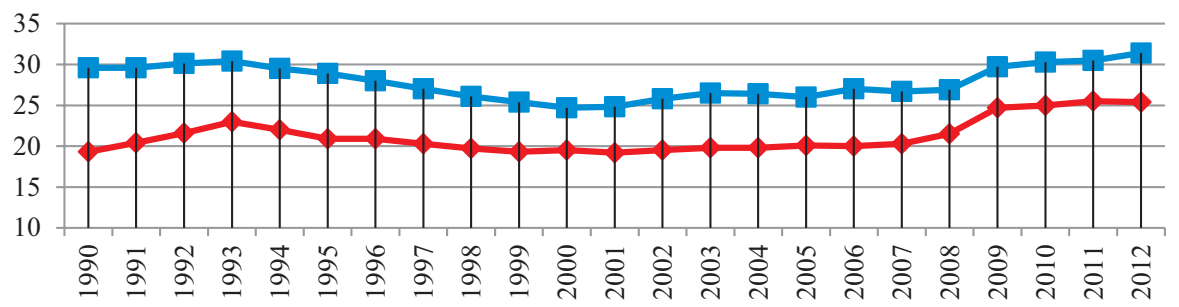

Fig. 6.29 Social expenditure as percentage of the GDP (Data from: Eurostat). Spain in Red, Netherlands in Light Blue 


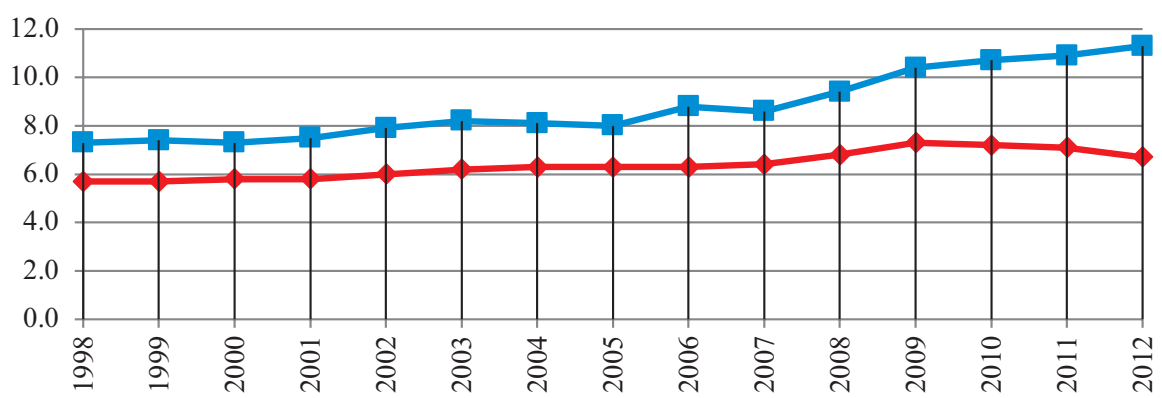

Fig. 6.30 Sickness and healthcare spending as percentage of the GDP (Data from: Eurostat). Spain in Red, Netherlands in Light Blue

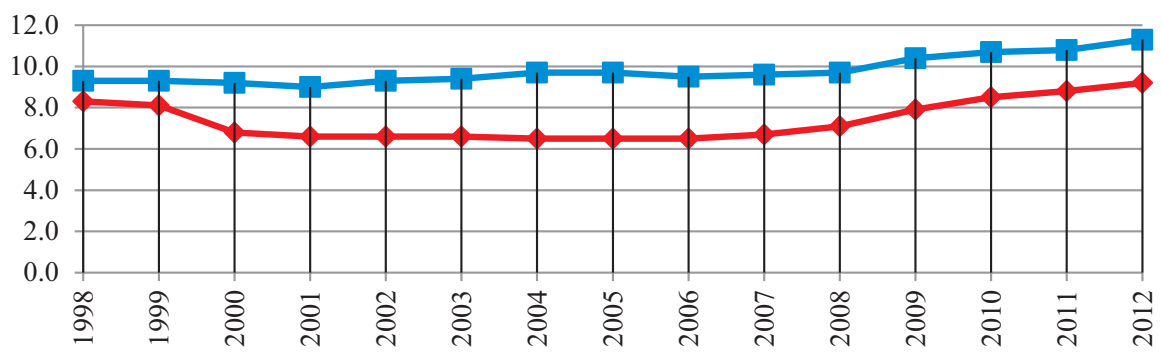

Fig. 6.31 Spending of old-age pensioners as percentage of the GDP (Data from: Eurostat). Spain in Red, Netherlands in Light Blue

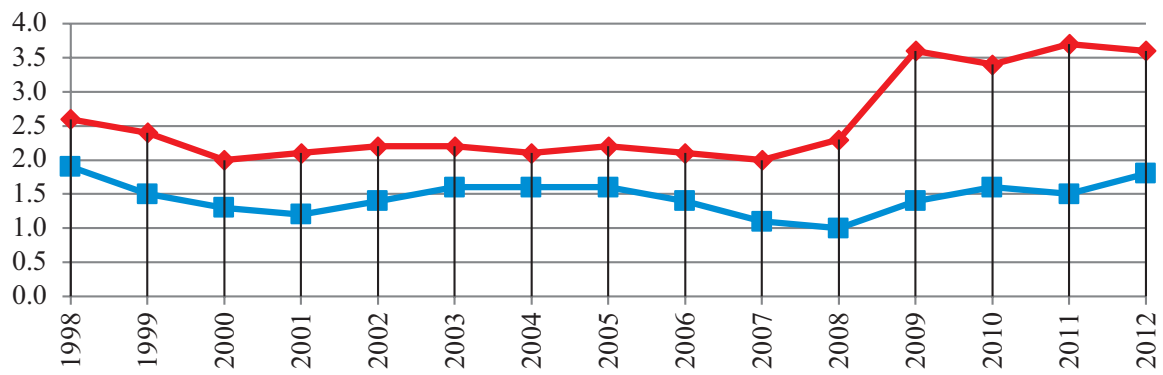

Fig. 6.32 Unemployment as percentage of the GDP (Data from: Eurostat). Spain in Red, Netherlands in Light Blue

In Figs. 6.30, 6.31, 6.32, and 6.33, it is possible to observe the social spending in the two countries in disaggregated terms. Each sector follows the general trend of the total figures. The only sector in which Spain spent more than the Netherlands is for the unemployment benefits. This is easily related to the different numerical relevance of the unemployed population. Noteworthy is also the case of Social Exclusion spending (Fig. 6.33) where a huge distance is observable between the two countries. 


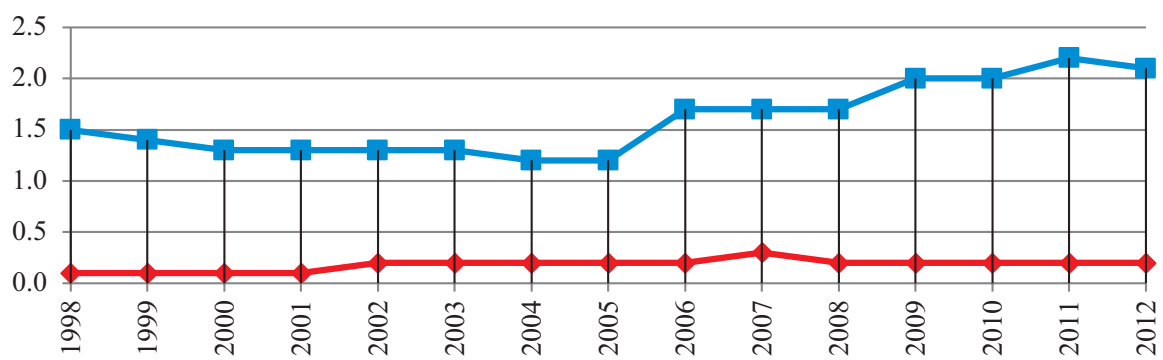

Fig. 6.33 Social exclusion spending as percentage of the GDP (Data from: Eurostat). Spain in Red, Netherlands in Light Blue

Hemerijck and his colleagues, more so on a qualitative level, have recently compared the welfare policies of the Netherlands and Spain (Hemerijck et al., 2013, pp. 8-9). In Table 6.2, it is possible to see the result of their comparison.

As can be observed, many relevant differences have been pinpointed. Whereas both welfare states have undergone processes of recalibration in recent decades, the Dutch government has been more effective in moving away from the limitations of the conservative model. In this respect, a number of important reforms have been introduced with the double objective of more efficient and universal social services, and a more flexible, yet supported, labour market (flexsecurity). In Spain, while important efforts have been made and noteworthy results have been attained, for instance, in the inclusion of women in the labour market, there is "the Bismarckian strand that still dominates the system as a whole; that is to say, what position in the labour market still counts more than citizenship, need or exclusion" (Rodríguez Cabrero, 2011, p. 34).

\subsubsection{Politics, Public Opinion, Migration}

Concerning the relation between politics, public opinion and migration, and given the complexity and sensitivity of the issue, it is certainly not easy to produce a concise comparison between the Netherlands and Spain. Therefore, it will be only possible to advance an impressionistic evaluation of the general trends based on the elements that emerged in the analysis previously proposed.

Following the analysis proposed by Arango, and using three elements (the public concern over migration, the politicization of immigration and the success of eventual populist parties, and the orientation of recent policy reforms and interventions in the immigration field) as a criterion to assess the general socio-political attitude towards migration, the Netherlands and Spain present a different picture.

Although the Netherlands had been a destination country beginning in the 1960s, migration became an issue of public and political concern in the 1990s. Since then and also in connection with a number of dramatic episodes at an international and national level, the social and political attitude towards migration has been increasingly complicated. The emergence of populist anti-immigration parties and their political success throughout the 2000 s, whether they are interpreted as a response to 
Table 6.2 Core principles of welfare regimes. (Hemerijck et al. 2013)

\begin{tabular}{|c|c|c|}
\hline & Netherlands & Spain \\
\hline Welfare regime type & Continental & Southern \\
\hline Core values & $\begin{array}{l}\text { Status preservation (equivalence } \\
\text { principle) }\end{array}$ & $\begin{array}{l}\text { Status preservation and } \\
\text { differentiation }\end{array}$ \\
\hline Objective & Income maintenance & Income maintenance \\
\hline Social rights & Employment based entitlements & Insider biased entitlements. \\
\hline \multirow[t]{2}{*}{ Employment } & $\begin{array}{l}\text { Ambiguous work ethic (differences } \\
\text { between Catholicism, Lutheranism } \\
\text { and Calvinism) }\end{array}$ & Weak work ethic \\
\hline & Full male employment & Full male employment \\
\hline Gender & $\begin{array}{l}\text { Nuclear family as cornerstone of } \\
\text { society }\end{array}$ & $\begin{array}{l}\text { Extended family as core welfare } \\
\text { provider }\end{array}$ \\
\hline Basis of entitlement & Work/family needs & Insider/family needs \\
\hline Responsibility & Collective & Collective \\
\hline \multicolumn{3}{|c|}{ Policy legacies, institutions and instruments of welfare regimes } \\
\hline \multirow[t]{2}{*}{ Social security } & $\begin{array}{l}\text { Social insurance financed high } \\
\text { (contribution contingent) transfers } \\
\text { (long duration) }\end{array}$ & $\begin{array}{l}\text { Social insurance financed } \\
\text { fragmented transfers (long } \\
\text { duration) }\end{array}$ \\
\hline & Separate public social assistance & No additional safety net \\
\hline $\begin{array}{l}\text { Labour market } \\
\text { policy / regulation }\end{array}$ & $\begin{array}{l}\text { Strong job protection, no active } \\
\text { market labour policy }\end{array}$ & $\begin{array}{l}\text { Strong job protection, no active } \\
\text { labour market policy }\end{array}$ \\
\hline Family support & Passive, but generous & Passive, but limited \\
\hline Beneficiaries & Male breadwinners & Labour market insiders \\
\hline \multirow[t]{2}{*}{ Actors in provision } & $\begin{array}{l}\text { State secondary to the social partners } \\
\text { (tripartims) and nuclear family } \\
\text { (subsidiary) }\end{array}$ & $\begin{array}{l}\text { Central role extended family } \\
\text { (state rudimentary) }\end{array}$ \\
\hline & Intermediary groups & Voluntary (church) organizations \\
\hline Industrial relation & $\begin{array}{l}\text { Sectorial-inclusive labour relation } \\
\text { (wide coverage) }\end{array}$ & $\begin{array}{l}\text { Politicized sector- and firm-based } \\
\text { labour relations (fragmented } \\
\text { coverage) }\end{array}$ \\
\hline
\end{tabular}

social anxiety or as its cause, certainly indicate a changed climate. Also considering the policies adopted since the 1990s, an increasingly restrictive attitude is evident. This has affected both migration control policies and integration policies. The former have been improved in a number of sectors. The objectives have been: to curtail entry channels both for legal and illegal migration, to discourage irregular residence and work, and to make expulsions an effective policy. As regards integration policies, both a discursive and practical departure from the multiculturalist paradigm has taken place. The new direction puts emphasis on civic and cultural integration and the acceptance of Dutch values as a necessary requirement for current and future immigrants.

The case of Spain has provided a different picture. It is certainly important to remember that the years in which migration emerged as a social problem in the Netherlands were the years in which it appeared as a social phenomenon in Spain. Yet, although conflictive episodes and moments of public concern over migration have existed, the general social climate towards migration can be judged as positive. 
No populist, anti-immigration parties or discourses have emerged. This has translated into an open policy towards migration, which has centred on creating legal channels for labour migration and fostering the integration of the newcomers (Table 6.3).

Table 6.3 Synoptic comparison: the Netherlands and Spain

\begin{tabular}{|c|c|c|c|}
\hline & & Netherlands & Spain \\
\hline \multirow[t]{4}{*}{$\begin{array}{l}\text { Migration } \\
\text { trends }\end{array}$} & Historical & $\begin{array}{l}\text { Old country of } \\
\text { migration (first, second } \\
\text { and third generations) }\end{array}$ & $\begin{array}{l}\text { Recent country of migration } \\
\text { (first, forming second } \\
\text { generation) }\end{array}$ \\
\hline & 1998-2013 & $\begin{array}{l}\text { Average } 90,000 \text { per } \\
\text { year. }\end{array}$ & Average 476,000 per year. \\
\hline & Irregularity & $\begin{array}{l}\text { Moderate until } 2002 \text {, } \\
\text { low afterwards. }\end{array}$ & $\begin{array}{l}\text { Very high until } 2005, \text { moderate } \\
\text { until } 2007 \text {, low afterwards. }\end{array}$ \\
\hline & Ecuadorians & $\begin{array}{l}\text { Very small community } \\
(3000)\end{array}$ & Very big community $(400,000)$ \\
\hline \multirow[t]{6}{*}{$\begin{array}{l}\text { Migration } \\
\text { Regime }\end{array}$} & \multirow[t]{2}{*}{ Legal channels } & $\begin{array}{l}\text { Narrow labour } \\
\text { migration channels. }\end{array}$ & $\begin{array}{l}\text { Narrow labour migration } \\
\text { channels (until 2004); Flexible } \\
\text { labour migration channels (from } \\
\text { 2005). }\end{array}$ \\
\hline & & $\begin{array}{l}\text { Broad asylum seeker } \\
\text { channels. }\end{array}$ & Narrow asylum seeker channels. \\
\hline & \multirow[t]{2}{*}{ Regularization } & $\begin{array}{l}\text { Very sporadic and } \\
\text { limited regularizations }\end{array}$ & $\begin{array}{l}\text { Recurrent, massive } \\
\text { regularizations }\end{array}$ \\
\hline & & $\begin{array}{l}\text { No permanent } \\
\text { regularization schemes. }\end{array}$ & $\begin{array}{l}\text { Available permanent } \\
\text { regularization schemes. }\end{array}$ \\
\hline & \multirow[t]{2}{*}{ Internal controls } & Strict after 1998 & Increasingly strict after 2005 \\
\hline & & $\begin{array}{l}\text { Irregular migrants } \\
\text { excluded from } \\
\text { healthcare and other } \\
\text { social services since } \\
1998 .\end{array}$ & $\begin{array}{l}\text { Irregular migrants excluded } \\
\text { from healthcare since } 2012 \text {. }\end{array}$ \\
\hline \multirow[t]{6}{*}{$\begin{array}{l}\text { Economy, } \\
\text { labour } \\
\text { market, } \\
\text { shadow } \\
\text { economy }\end{array}$} & \multirow[t]{2}{*}{ GDP } & $\begin{array}{l}\text { Booming economy } \\
1994-2000 \text { and } \\
2006-2007 \text { (GDP over } \\
2.5 \%)\end{array}$ & $\begin{array}{l}\text { Booming economy } 1995-2007 \\
\text { (GDP over } 2.5 \%)\end{array}$ \\
\hline & & $\begin{array}{l}\text { Mild economic crisis } \\
\text { since } 2009 .\end{array}$ & $\begin{array}{l}\text { Deep economic crisis since } \\
2009 .\end{array}$ \\
\hline & \multirow[t]{2}{*}{ Labour market } & $\begin{array}{l}\text { Slow growth of total } \\
\text { employment. }\end{array}$ & $\begin{array}{l}\text { Huge creation of jobs between } \\
1998 \text { and } 2007 \text { (+6.5 millions). } \\
\text { Huge destruction of jobs } \\
\text { between } 2008 \text { and } 2013 \text { (-3.4 } \\
\text { millions) }\end{array}$ \\
\hline & & $\begin{array}{l}\text { Unemployment: stable, } \\
\text { very low } \\
\text { unemployment }\end{array}$ & $\begin{array}{l}\text { Unemployment: significantly } \\
\text { decreasing until 2007; steeply } \\
\text { rising in the years to follow. }\end{array}$ \\
\hline & Sectors & $\begin{array}{l}\text { Limited low-skilled } \\
\text { sectors }\end{array}$ & Important low-skilled sectors. \\
\hline & Shadow economy & $14-9 \%$ & $24-19 \%$. \\
\hline
\end{tabular}


Table 6.3 (continued)

\begin{tabular}{|c|c|c|c|}
\hline \multirow{5}{*}{ Welfare state } & & Netherlands & Spain \\
\hline & Type & Conservative & Southern/Mediterranean \\
\hline & Main principles & $\begin{array}{l}\text { Social insurance }+ \\
\text { Social assistance }\end{array}$ & Social insurance \\
\hline & $\%$ of GDP & Between $25 \%$ and $30 \%$ & Between $20 \%$ and $25 \%$ \\
\hline & $\begin{array}{l}\text { Main universal } \\
\text { services }\end{array}$ & $\begin{array}{l}\text { Education, Healthcare, } \\
\text { Old age pensions, Old } \\
\text { age assistance }\end{array}$ & $\begin{array}{l}\text { Education, Healthcare, Old age } \\
\text { pensions }\end{array}$ \\
\hline \multirow[t]{4}{*}{$\begin{array}{l}\text { Politics, } \\
\text { public } \\
\text { opinion, } \\
\text { migration }\end{array}$} & \multirow[t]{2}{*}{$\begin{array}{l}\text { Anti-immigration } \\
\text { discourses and } \\
\text { political parties }\end{array}$} & $\begin{array}{l}\text { Increasing importance } \\
\text { of anti-immigration } \\
\text { discourses in public and } \\
\text { political debates. }\end{array}$ & $\begin{array}{l}\text { No anti-immigrant discourses at } \\
\text { a national level. }\end{array}$ \\
\hline & & $\begin{array}{l}\text { Anti-immigration } \\
\text { parties in the } \\
\text { Parliament and in the } \\
\text { Government. }\end{array}$ & No anti-immigrant parties. \\
\hline & $\begin{array}{l}\text { Public concern } \\
\text { over migration }\end{array}$ & High to moderate. & Low to moderate. \\
\hline & $\begin{array}{l}\text { Restrictive } \\
\text { integration } \\
\text { policies }\end{array}$ & $\begin{array}{l}\text { Increasingly restrictive } \\
\text { policies since } 1990 \mathrm{~s} .\end{array}$ & $\begin{array}{l}\text { Liberal policies until } 2012 \text {; then } \\
\text { increasingly restrictive. }\end{array}$ \\
\hline
\end{tabular}

\section{Bibliography}

Acosta, A. (1998). Breve historia económica del Ecuador. Quito, Ecuador: Corporación Editora Nacional.

Aja, E. (2009a). La reforma de la Ley de Extranjería. In E. Aja, J. Arango, \& J. Oliver Alonso (Eds.), La inmigración en tiempos de crisis. Anuario de la inmigración en España 2009 (pp. 18-40). Barcelona, Spain: CIDOB.

Aja, E. (Ed.). (2009b). Los derechos de los inmigrantes en España. Valencia, Spain: Tirant lo Blanch.

Aja, E., \& Arango, J. (2006). Veinte años de inmigración en España: perspectivas jurídica y sociológica (1985-2004). Barcelona, Spain: CIDOB.

Aja, E., Arango, J., \& Oliver Alonso, J. (2012). La hora de la Intergación. Anuario de Inmigración en España 2011. Barcelona, Spain: CIDOB.

Arango, J. (2005). La inmigración en España: demografía, sociología y economía. In R. del Águila (Ed.), Inmigración: Un desafio para España (pp. 247-273). Madrid, Spain: Editorial Pablo Iglesias.

Arango, J. (2010). Después del gran "boom": la inmigración en la bisagra del cambio. In E. Aja, J. Arango, \& J. Oliver Alonso (Eds.), La inmigración en tiempos de crisis. Anuario de la inmigración en España 2009 (pp. 52-73). Barcelona, Spain: CIDOB.

Arango, J. (2013). Exceptional in Europe? Spain's experience with immigration and integration. Washington DC: Migration Policy Institute.

Arango, J., \& Finotelli, C. (2009). Past and future challenges of a Southern European migration regime: The Spanish case.

Arango, J., \& Jachimowicz, M. (2005). Regularizing immigrants in Spain: A new approach. Migration Information Source, 1(9), 2005. 
Arango, J., Moya Malapeira, D., \& Oliver Alonso, J. (2014). 2013: ¿Un año de transición? In J. Arango, D. Moya Malapeira, \& J. Oliver Alonso (Eds.), Inmigración y Emigración: mitos y realidades. Anuario de la inmigración en España 2013 (pp. 12-27). Barcelona, Spain: CIDOB.

Boccagni, P. (2007). Votare, per noi, era un giorno di festa. Un'indagine esplorativa sul transnazionalismo politico tra gli immigrati ecuadoriani in Italia. Roma, CeSPI Working Paper, 35, 2007.

Broeders, D. (2009). Breaking down anonymity digital surveillance on irregular migrants in Germany and the Netherlands. Rotterdam, The Netherlands: Erasmus Universiteit.

Broeders, D., \& Engbersen, G. (2007). The fight against illegal migration: Identification policies and immigrants' counterstrategies. American Behavioral Scientist, 50(12), 1592-1609. https:// doi.org/10.1177/0002764207302470

Cachón, L. (2007). Diez notas sobre la inmigración en España 2006. Vanguardia Dossier, 22, 68-74.

Cachón, L. (2009). La España inmigrante: marco discriminatorio, mercado de trabajo y políticas de integración. Barcelona, Spain: Anthropos Editorial.

Cea D’Ancona, M. Á. (2011). Estabilidad y cambios de las actitudes ante la inmigración: un análisis cuantitativo. In E. Aja, J. Arango, \& J. Oliver Alonso (Eds.), Inmigración y crisis económica. Impactos actuales y perspectivas de futuro. Anuario de la inmigración en España. Edición 2010 (pp. 49-74). Barcelona, Spain: CIDOB.

Cea D’Ancona, M. Á., \& Valles Martínez, M. (2013). Evolución del racismo, la xenofobia y otras formas conexas de intolerancia en España. Informe 2013. Madrid, Spain: Ministerio de Empleo y Seguridad Social - Observatorio Español del Racismo y la Xenofobia.

Cebolla, H., \& González Ferrer, A. (2008). La inmigración en España (2000-2007). Madrid, Spain: Centro de Estudios Políticos y Constitucionales.

Cvajner, M., Echeverría, G., \& Sciortino, G. (2018). What do we talk when we talk about migration regimes? The diverse theoretical roots of an increasingly popular concept. In A. Pott, C. Rass, \& F. Wolff (Eds.), Was ist ein Migrationsregime? What is a migration regime? (pp. 65-80). Wiesbaden, Germany: Springer Fachmedien Wiesbaden. https://doi. org/10.1007/978-3-658-20532-4_3

Echeverría, J. (1997). La democracia bloqueada. Teoría y crisis del sistema político ecuatoriano. Quito, Ecuador: Letras.

Echeverría, G. (2010). L'immigrazione irregolare in Spagna: fra politiche di controllo e crisi economica. Uno sguardo ai numeri. Neodemos.It.

Echeverría, G. (2014a). Between territoriality, identity, and politics: The external vote of Ecuadorians in Madrid. In M. La Barbera (Ed.), Identity and migration in Europe: Multidisciplinary perspectives (pp. 175-191). Dordrecht, The Netherlands: Springer.

Echeverría, G. (2014b). De la "Producción institucional de la Irregularidad" a la "Irregularidad Sobrevenida": diez años de política migratorias en España. In M. Fernández (Ed.), Negociaciones identitarias de la población migrante (pp. 11-23). Madrid, Spain: Common Ground Publisher.

Engbersen, G. (2001). The unanticipated consequences of Panopticon Europe. In V. Guiraudon \& C. Joppke (Eds.), Controlling a new migration world (pp. 222-246). London, New York: Routledge.

Engbersen, G., \& Broeders, D. (2009). The state versus the Alien: Immigration control and strategies of irregular immigrants. West European Politics, 32(5), 867-885. https://doi. org/10.1080/01402380903064713

Engbersen, G., Staring, R., Van Der Leun, J., de Boom, J., van der Heijden, P., \& Cruijff, M. (2002). Illegale vreemdelingen in Nederland: omvang, overkomst, verblijf en uitzetting.

Engbersen, G., \& Van Der Leun, J. (2001). The social construction of illegality and criminality. European Journal on Criminal Policy and Research, 9(1), 51-70.

Engbersen, G., Van Der Leun, J., \& Leerkes, A. (2004). The Dutch migration regime and the rise in crime among illegal immigrants (pp. 25-28). Presented at the fourth annual conference of the European Society of Criminology, Global Similarities, Local Differences. Amsterdam, August. 
Entzinger, H. (2006). The parallel decline of multiculturalism and the welfare state in the Netherlands. In Banting \& W. Kymlicka (Eds.), Multiculturalism and the welfare state. Recognition and redistribution in contemporary democracies. Oxford, UK: Oxford University Press.

Esping-Andersen, G. (1990). The three worlds of welfare capitalism. Princeton NJ: Princeton University Press.

Esping-Andersen, G. (1996a). After the golden age? Welfare state dilemmas in a global economy. In G. Esping-Andersen (Ed.), Welfare states in transition: National adaptations in global economies (pp. 1-31). London: Sage.

Esping-Andersen, G. (Ed.). (1996b). Welfare states in transition: National adaptations in global economies. London: Sage.

Ferrera, M. (1996). The "Southern model" of welfare in social Europe. Journal of European Social Policy, 6(1), 17-37.

Ferrera, M. (2008). The European welfare state: Golden achievements, silver prospects. West European Politics, 31(1-2), 82-107. https://doi.org/10.1080/01402380701833731

Ferrera, M., Hemerijck, A., \& Rhodes, M. (2000). The future of social Europe: Recasting work and welfare in the new economy. Oeiras, Portugal: Celta Editora Oeiras.

Finotelli, C. (2012). Labour migration governance in contemporary Europe. The case of Spain (LAB-MIG-GOV Project - Which labour migration governance for a more dynamic and inclusive Europe). Torino: FIERI.

Finotelli, C., \& Arango, J. (2011). Regularisation of unauthorised immigrants in Italy and Spain: Determinants and effects. Documents d'anàlisi Geogràfica, 57(3), 495-515.

Finotelli, C., \& Echeverría, G. (2017). So close but yet so far? Labour migration governance in Italy and Spain. International Migration, 55, 39-51. https://doi.org/10.1111/imig. 12362

Gal, J. (2010). Is there an extended family of Mediterranean welfare states? Journal of European Social Policy, 20(4), 283-300.

Garcés-Mascareñas, B. (2011). "Truble in Paradise". Reflexiones sobre los discursos y las políticas en torno al asesisanto the Theo van Gogh. In L. Cachón (Ed.), Inmigración y conflictos en Europa (pp. 231-270). Barcelona, Spain: Hacer.

Godenau, D., Hernández, V. M. Z., \& Expósito, C. B. (2007). La inmigración irregular en Tenerife. Tenerife, Spain: Cabildo de Tenerife, Área de Desarrollo Económico.

Gómez Ciriano, E. J., Tornos Cubillo, A., \& Colectivo, I. O. E. (2007). Ecuatorianos en España: una aproximación sociológica. Madrid, Spain: Ministerio de Trabajo y Asuntos Sociales.

González-Enríquez, C. (2009). Undocumented migration: Counting the uncountable. Data and trends across Europe. Country Report Spain. Report Prepared for the Research Project CLANDESTINO.

Guillén, A. M. (2010). Defrosting the Spanish welfare state: The weight of conservative components. In B. Palier (Ed.), A long goodbye to Bismarck: The politics of welfare refroms in continental welfare states (pp. 183-206). Amsterdam: Amsterdam University Press.

Guillén, A. M., \& León, M. (2011). The Spanish welfare state in European context. Farnham, UK: Ashgate Publishing, Ltd..

Hemerijck, A. (2012). Changing welfare states. Oxford, UK: Oxford University Press.

Hemerijck, A., Keune, M., \& Rhodes, M. (2006). European welfare states: Diversity, challenges and reforms. In P. M. Heywood, E. Jones, M. Rhodes, \& U. Sedelmeier (Eds.), Developments in European politics (pp. 259-279). New York: Palgrave Macmillan.

Hemerijck, A., Palm, T., Entenmann, E., \& Van Hooren, F. (2013). Welfare states and the evolution of migrant incorporation regimes (IMPACIM - The impact of restrictions and entitlement on the integration of family migrants). VU Univeristy of Amsterdam - COMPAS, University of Oxford.

Herrera, G. (2007). Ecuatorianos/as en Europa: de la vertiginosa salida a la contrucción de espacios transnacionales. In Nuevas migraciones latinoamericanas a Europa. Balances y desafíos. Quito, Ecuador: FLACSO.

Herrera, G. (Ed.). (2008). Ecuador: la migración en cifras. Quito, Ecuador: FLACSO-UNFPA. 
Herrera, G., Moncayo, M. I., \& Escobar, A. (2012). Perfil Migratorio del Ecuador, 2011. Geneva, Switzerland: Organización Internacional para las Migraciones (OIM).

Hoogteijling, E. (2002). Raming van het aantal niet in de GBA geregistreerden. Voorburg, The Netherlands: Centraal Bureau voor de Statistiek.

INDIAC - NL EMN NCP. (2012). In D. Diepenhorst (Ed.), Practical measures for reducing irregular migration in the Netherlands. Rijswijk, The Netherlands: INDIAC - NL EMN NCP.

INEC. (2013). Anuario de Estadísticas de Entradas y Salidas Internacionales 2013. Quito, Ecuador: Instituto Nacional de Estadística y Censos.

Izquierdo, A. (1996). La inmigración inesperada. Madrid, Spain: Editorial Trotta.

Izquierdo, A. (2009). El modelo de inmigración y los riesgos de exclusión. In VI Informe sobre exclusión y desarrollo social en España: 2008 (pp. 599-679). Madrid, Spain: Fundación Fomento de Estudios Sociales y de Sociología Aplicada, FOESSA.

Kloosterman, R., Van Der Leun, J., \& Rath, J. (1999). Mixed embeddedness: (In) formal economic activities and immigrant businesses in the Netherlands. International Journal of Urban and Regional Research, 23(2), 252-266.

Leerkes, A. (2009). Illegal residence and public safety in the Netherlands. Amsterdam: Amsterdam University Press.

Leerkes, A. (2016). Back to the poorhouse? Social protection and social control of unauthorised immigrants in the shadow of the welfare state. Journal of European Social Policy, 26(2), 140 154. https://doi.org/10.1177/0958928716637139

Leerkes, A., van San, M., Engbersen, G., Cruijff, M., \& van der Heijden, P. (2004). Wijken voor illegalen. Over ruimtelijke spreiding, huisvesting en leefbaarheid. Den Haag, The Netherlands: Sdu Uitgevers bv.

Lucassen, L. (2001). A many-headed monster: The evolution of the passport system in the Netherlands and Germany in the long nineteenth century. In J. Caplan \& J. Torpey (Eds.), Documenting individual identity. The development of state practices in the modern world (pp. 235-255). Princeton, NJ: Princeton University Press.

Martínez Veiga, U. (2003). Pobreza absoluta e inmigración irregular: la experiencia de los inmigrantes sin papeles en España. Papeles de Economía Española, (98), 214-224.

Montilla, J. A., \& Rodríguez, J. L. (2012). Las normas generales del Estado en materia de inmigración en el año 2012. In Inmigración y crisis: entre la continuidad y el cambio. Anuario de la inmigración en España. Barcelona, Spain: CIDOB.

Montilla, J. A., Rodríguez, J. L., \& Lancha, M. (2011). Las normas generales del Estado sobre inmigración en 2011. In E. Aja, J. Arango, \& J. Oliver Alonso (Eds.), La hora de la Intergación. Anuario de Inmigración en España 2011 (pp. 312-355). Barcelona, Spain: CIDOB.

Moreno, L. (2001). Spain, a via media of welfare development. In P. Taylor-Gooby (Ed.), Welfare states under pressure (pp. 100-122). London: Sage.

Moreno, J., \& Bruquetas, M. (2012). Las políticas sociales y la integración de la población de origen inmigrante en España. In E. Aja, J. Arango, \& J. Oliver Alonso (Eds.), La hora de la Intergación. Anuario de Inmigración en España 2011 (pp. 158-186). Barcelona, Spain: CIDOB.

Penninx, R. (2006). After the Fortuyn and Van Gogh murders: Is the Dutch integration model in disarray? In S. Delorenzi (Ed.), Going places. Neighbourhood, ethnicity and social mobility (pp. 127-138). London: Institute for Public Policy Research.

Ramírez, F., \& Ramírez, J. (2005). La estampida migratoria ecuatoriana. Crisis, redes transnacionales y repertorio de acción migratoria. Quito, Ecuador: Ciudad - Unesco - Abya Yala - Alisei.

Recaño, J., \& Domingo, A. (2005). Factores sociodemográficos y territoriales de la inmigración irregular en España (pp. 18-23). Presented at the XXV International Population Conference, Tours, Francia.

Rodríguez Cabrero, G. (2011). The consolidation of the Spanish welfare state (1975-2010). In A. M. Guillén \& M. León (Eds.), The Spanish welfare state in European context. Farnham: Ashgate (pp. 17-38). Farnham, UK: Ashgate Publishing, Ltd.. 
Schneider, F., Buehn, A., \& Montenegro, C. E. (2010). New estimates for the shadow economies all over the world. International Economic Journal, 24(4), 443-461.

Schneider, F., Raczkowski, K., Mróz, B., \& Futter, A. (2015). Shadow economy and tax evasion in the EU. Journal of Money Laundering Control, 18(1), 34-51.

Van der Heijden, P. G., Gils, G. V., Cruijff, M., \& Hessen, D. (2006). Een schatting van het aantal in Nederland verblijvende illegale vreemdelingen in 2005. IOPS-Utrecht: Universiteit Utrecht.

Van der Heijden, P. G., Cruyff, M., \& Van Gils, G. H. (2011). Schattingen illegaal in Nederland verblijvende vreemdelingen 2009.

Van Der Leun, J. (2003). Looking for loopholes: Processes of incorporation of illegal immigrants in the Netherlands. Amsterdam: Amsterdam University Press.

Van Der Leun, J. (2006). Excluding illegal migrants in The Netherlands: Between national policies and local implementation. West European Politics, 29(2), 310-326. https://doi. org/10.1080/01402380500512650

Van der Leun, J., \& Bouter, H. (2015). Gimme shelter: Inclusion and exclusion of irregular immigrants in Dutch civil society. Journal of Immigrant \& Refugee Studies, 13(2), 135-155. https:// doi.org/10.1080/15562948.2015.1033507

Van Der Leun, J., \& Ilies, M. (2008). Undocumented migration, counting the uncountable. Data and trends across Europe. Country report The Netherlands. 6th Framework Programme of the European Union.

Van Meeteren, M. (2010). Life without papers: Aspirations, incorporation and transnational activities of irregular migrants in the Low Countries. Rotterdam, The Netherlands: Erasmus Universiteit.

Van Meeteren, M., Van de Pol, S., Dekker, R., Engbersen, G., \& Snel, E. (2013). Destination Netherlands. History of immigration and immigration policy in the Netherlands. In Immigrants: Acculturation, socioeconomic challenges and cultural psychology. New York: Nova Science Publishers, Inc.

Van Nieuwenhuyze, I. (2009). Getting by in Europe's urban labour markets: Senegambian migrants' strategies for survival, documentation and mobility. Amsterdam: Amsterdam University Press.

Open Access This chapter is licensed under the terms of the Creative Commons Attribution 4.0 International License (http://creativecommons.org/licenses/by/4.0/), which permits use, sharing, adaptation, distribution and reproduction in any medium or format, as long as you give appropriate credit to the original author(s) and the source, provide a link to the Creative Commons licence and indicate if changes were made.

The images or other third party material in this chapter are included in the chapter's Creative Commons licence, unless indicated otherwise in a credit line to the material. If material is not included in the chapter's Creative Commons licence and your intended use is not permitted by statutory regulation or exceeds the permitted use, you will need to obtain permission directly from the copyright holder.

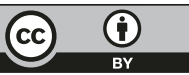

